\title{
A new teleost (Osteichthyes, Actinopterygii) from the Early Jurassic Posidonia shale of Northern Germany
}

\author{
Gloria Arratia ${ }^{1}$ \& Detlev Thies ${ }^{2}$
}

With 13 figures, 1 table, and 1 appendix

\begin{abstract}
A new telcostean genus and species, Paraleptolepis wiedenrothi, is described from the Lower Liassic of Germany. The fish has an overall similarity with Leptolepis coryphaenoides (from different Lower Liassic European localities) but differs from L. coryphaenoides in the presence of a few autapomorphics and also in the retention of several primitive features not present in L. coryphaenoides. Examples of autapomorphic characters are: two moderately large suborbital bones; preopercle triangular and with a notch at its posterior margin; large cleithrum with pronounced curvature anteriorly; pelvic axillary process formed by one small elongate bone; and long neural spines on preural centrum 1 and the ural centrum $1+2$. Paraleptolepis $\mathrm{n}$. gen. is more closely related to Leptolepis and extant teleosts than it is to Proleptolepis (from Lower Liassic localities). The new evidence supports the previous hypothesis that the family Leptolepididae sensu Nybelin is non-monophyletic. Several characters (e.g., concerning structure of vertebrae) that previously were accepted to have arisen at the phylogenetic level of Leptolepis coryphaenoides, are found also to occur in Paraleptolepis n. gen.
\end{abstract}

Key words: Fishes, Teleostei, Early Jurassic, Proleptolepis, Leptolepis, Paraleptolepis n. gen.

\section{Zusammenfassung}

Eine neue Teleosteergattung und -art, Paraleptolepis wiedenrothi, wird aus dem unteren Lias Deutschlands beschricben. Der Fisch hat eine generelle Ähnlichkeit mit Leptolepis coryphaenoides (bekannt von verschiedenen europäischen Lokalitäten des unteren Lias), aber unterscheidet sich von L. coryphaenoides in einigen Autapomorphien und in der Beibehaltung mehrerer primitiver Merkmale, die in $L$. coryphaenoides nicht vorhanden sind. Beispiele autapomorpher Merkmale sind: zwei vcrhältnismäßig große suborbitale Knochen; ein dreieckiges Präoperculum mit einer Einbuchtung am hinteren Rand; ein großes Cleithrum mit einer ausgeprägten vorderen Einbuchtung; ein Axillarfortsatz am Beckengürtel, der aus einem schmalen langen Knochen gebildet wird; und lange Neuralfortsätze auf dem präuralen Zentrum 1 und dem uralen Zentrum $1+2$. Paraleptolepis n. gen. ist näher mit Leptolepis und lebenden Teleosteern verwandt als mit Proleptolepis (aus Lokalitäten des unteren Lias). Die neuen Ergebnisse unterstützen die frühere Hypothese, dass die Familie Leptolepididae sensu Nybelin nicht monophyletisch ist. Verschiedene Merkmale (z. B. Strukturen der Wirbel), die früher als auf der Evolutionshöhe von Leptolepis coryphaenoides entstanden angesehen wurden, treten bereits bei Paraleptolepis n. gen. auf.

Schlüsselwörter: Fische, Teleosteer, unterer Jura, Proleptolepis, Leptolepis, Paraleptolepis n. gen.

\section{Introduction}

The Lower Jurassic (Lower Toarcian) Posidonia shale is a sequence of finely laminated bituminous marls subdivided by several more calcareous, harder horizons ("Fleins"). Famous outcrops are located at the villages of Holzmaden, Ohmden, Boll, and Zell southeast of the city of Stuttgart in Baden-Württemberg (southern Germany). The Posidonia shale has been exploited for the last several centuries. The most calcareous and hardest horizon, the so-called "Tafelfleins", was used to produce shingles and floor covering; in addition, oil has been extracted from the bituminous parts of the shale. Today, the "Fleins" horizons are still used for interior decoration.

The Posidonia shale is one of the richest fossillagerstätte in the world. The most spectacular of the vertebrates are the ichthyosaurs, featured in many museum exhibitions. Among the vertebrates the fossil fishes are most numerous. At least 15 genera of fossil bony fishes have been described to date (Hauff \& Hauff 1981, Delsate 1999). Unfortunately, most of these have not

\footnotetext{
1 Museum für Naturkunde, Institut für Paläontologie, Invalidenstr. 43, D-10115 Berlin, Germany.

2 Institut für Geologie und Paläontologie der Universität Hannover, Callinstr. 30, D-30167. Hannover, Germany. Received March 2001, accepted June 2001
} 
been revised s nee the time of A. S. Woodward (1895).

The reputat on of the Posidonia shale as a world-renowned fossillagerstätte is based primarily on the southern German outcrops. It is less well-known that occurrences in northern Germany are very fossiliferous as well. in particular the outcrops cround the city of Braunschweig. Even though t le shale has never becn exploited industrially, a ich array of fossil vertebrates has been collected from the Posidonia shale by amateur paleontologists during the last five decades. Based on matcrial from the Braunschweig area. Thies (1985, 1988, 1989, 1991) redescribed and revised representatives of the saurichthyiform genus Acidorh nchus Stensio. 1925 and the halecostome gener Dapedium Leach. 1822 and Tetragonolepis Bror n. 1830. The most common fishes found in the rosidonia shale are. however. the species of the teleostean genus Leptolepis Agassiz, 1832. Leptolepis from the Posidonia shale. or contemporanecus European geological formations, was considered in detail by Rayner (1937). Wenz (1968), Nybelin (1974). Patterson (1975). Taverne (1975). Patterson \& Rosen (1977). Arratia (1991, 1994, 1996. 1997). and Delsate (1997). The other telcostean genus known to occur in the Posidonia shale is Pholidophorus Agassiz. 1832 (Hauff \& Hauff 1981). This list. however. is not complete. Here wo describe. and consider the phylogenetic relationships of a well preserved fossil fi: hrom the Posidonia shale of the Braunschweig area that represents a new genus and species of teleost.

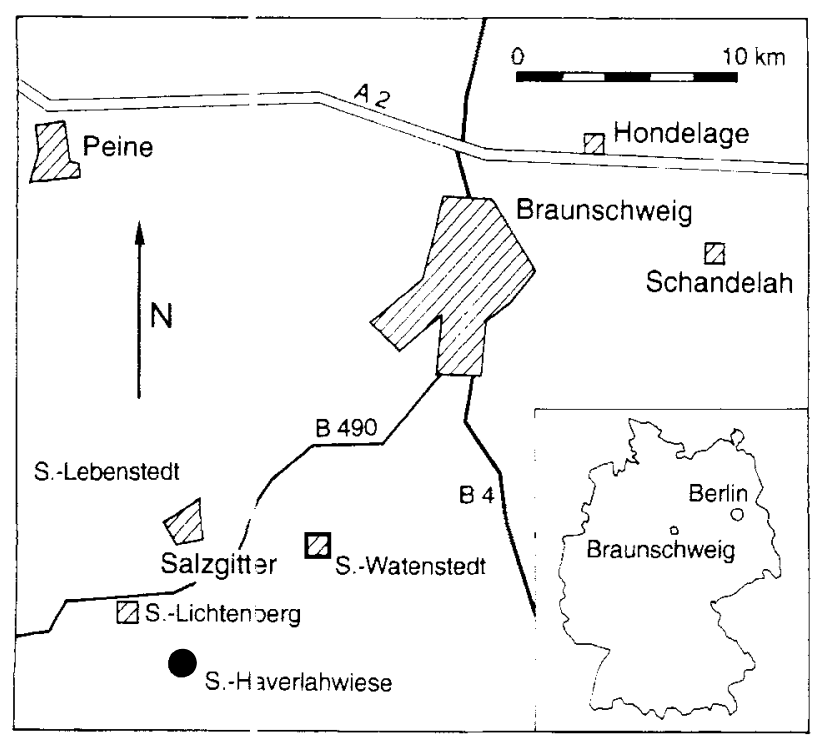

Fig. 1. Geographical sketch map showing the position of Salzgitter-Haverlal wiese (after Thies 1985). The black dot indicates the position of the open iron mine where the specimen was found. Hatching indicates populated areas (cities and communities). S.-. Sazgitter-

\section{Locality, and age}

The holotype was collected in an abandoned and recultivated open iron mine situated in the community of Salzgitter-Haverlahwiese, ca. $25 \mathrm{~km}$ SW of the city of Braunschweig in N Germany. (Grid ref.: Topographical map of Germany $1: 25.000$, sheet no. 3827 Lebenstedt-West, $\mathrm{R}$ ca. $3589900 . \mathrm{H}$ ca. 5776000$)$. The geographical setting of the locality is shown in Figure 1.

The rocks exposed at the locality range from the middle/upper Lower Jurassic to the Lower Cretaceous. The specimen was collected from the borealis-nodule layer, which is part of the Posidonia shale sequence (lower Toarcian, upper Lower Jurassic). The ammonites and the stratigraphy of the Posidonia shale in NW Germany last were studied by Weitschat (1973) - according to him the borealis-nodule layer belongs to

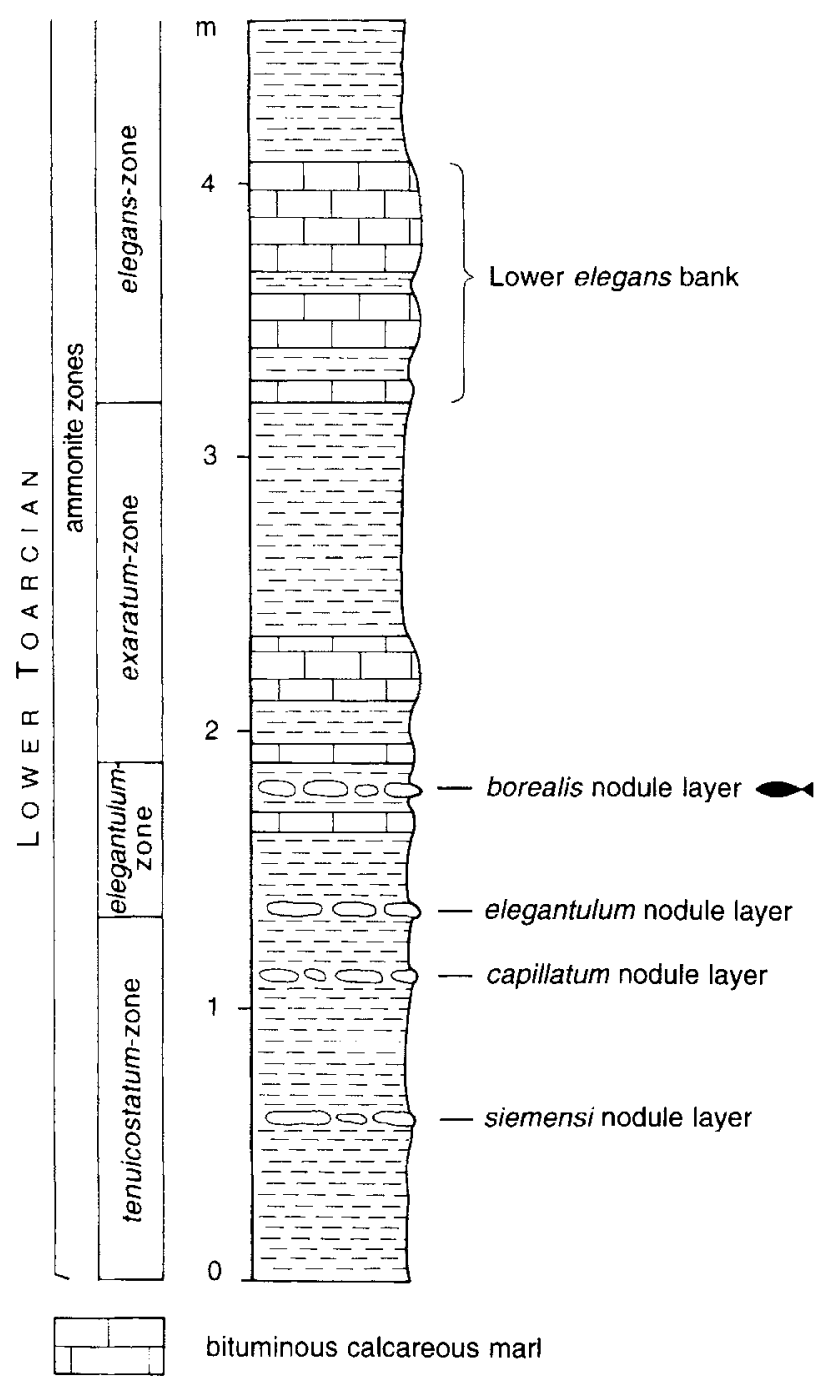

Fig. 2. Schematic profile of the lower and a part of the middle Posidonia shale (Lower Jurassic, Lower Toarcian) of the Braunschweig area. N Germany (redrawn after Wunnenberg 1950. zonation after Weitschat 1973). The fish indicates the horizon the specimen comes from. 
the elegantulum ammonite zone (= basal part of the traditional boreal falciferum ammonite zone). A schematic stratigraphic section of the lower and middle part of the Posidonia shale in the Braunschweig area ( $\mathrm{N}$ Germany) is given in Figure 2.

\section{Material and methods}

The comparative fossil material examined belongs to the following institutions:

ANSP, Academy of Natural Sciences of Philadelphia, Philadelphia, Pennsylvania, USA; BGHan, Bundesanstalt für Geowissenschaften und Rohstoffe, Niedersächsisches Landesamt für Bodenforschung. Hannover; GOE, Institut und Museum für Geologie and Paläontologie, Georg-August Universität, Göttingen; MB, Institut für Paläontologie, Museum für Naturkunde der Humboldt Universität, Berlin; MCZ, Museum of Comparative Zoology, Harvard University, Cambridge. Massachusetts, USA; and MNHN-SGO, Museo Nacional de Historia Natural, Santiago, Chile.

The material of the new taxon consists of one complete and articulated skeleton of a fossil fish. The specimen is housed in the collection of the Museum für Naturkunde der Humboldt-Universität at Berlin (Germany) under the catalogue no. MB. f.7612. G. Arratia has seen other specimens belonging to the new taxon. However, the specimens are in private collections and we cannot include them.

Numerous specimens of Leptolepis coryphaenoides have been studied for comparison: ANSP 7849, ANSP 14596; BGHan 1956-8, BGHan 1957-1, BGHan 1957-2, BGHan 1957-5 (all acid-prepared specimens); GOE, numerous uncatalogued specimens; MCZ 5069a, b (holotype). Numerous specimens of proleptolepids (MNHN SGO.PV uncat.) were also examined.

Methods of preparation: Most of the specimens have been mechanically prepared. Some specimens of Leptolepis coryphaenoides were acid-prepared following the procedure by Toombs \& Rixon (1959).

Phylogenetic methods: The phylogenetic relationtships as well as the importance of some of the characters used in the diagnosis of the new genus were tested performing a cladistic analysis using PAUP 4.0b4a of D. L. Swofford (1998; Phylogenetic Analysis Using Parsimony) on a Macintosh computer. Polarization of characters was done by outgroup comparison with taxa previously suggested as close outgroups of Teleostei - the amiiform Amia, the aspidorhynchiforms Aspidorhynchus and Belonostomus, and the pachycormiforms Hypsocormus and Pachycormus. A matrix of 14 taxa and 84 characters was built. Most characters were taken from Arratia (1999). All characters were interpreted as independent and run unordered in the computer analyses.

Terminology: Following the homologization of dermal skull bones in osteichthyans (e.g., Jollie 1962, Schultze \& Arsenault 1985. Schultze 1993, Arratia \& Cloutier 1996), we identify the so-called frontal in actinopterygians as the parietal and the so-called parietal as the postparietal throughout this paper. For the terminology of the caudal skeleton we follow Arratia \& Schultze (1992).

\section{Systematic paleontology}

Division Teleostei sensu Arratia, 1999

Teleostei incertae sedis

Family indeterminate

\section{Paraleptolepis n. gen.}

Diagnosis (based on a unique combination of features including several autapomorphies): Elongate, fusiform fish with few skull bones with a thin layer of ganoine and lacking ornamentation. Premaxilla with well-defined, long ascending process; with few conic teeth on oral margin. Two moderately large suborbital bones (*). Preopercle subtriangular in outline and with a notch at its posterior margin (*); most tubules of preopercular sensory canal not reaching the ventral and posterior margins of preopercle. Opercle slightly triangular and with crenulate posterior margin (*). Subopercle larger than opercle and broadly expanded postero-ventrally $(*)$. Large cleithrum with a pronounced curvature at its anterior margin $(*)$. Pelvic axillary process formed by only an elongate small bone $(*)$. Caudal skeleton with narrow, elongate neural spines. Preural centrum 1 with long neural spine. Ural centrum $1+2$ with unfused neural arch bearing an elongate spine. Both epaxial and hypaxial fringing fulcra. Two dorsal and one ventral caudal scutes. Thin cycloid scales lacking ganoine. (Unique characters among basal teleosts are identified by $\left.\left[{ }^{*}\right]\right)$.

Etymology: The name of the genus refers to the overall similarity to Leptolepis.

Type species: Paraleptolepis wiedenrothi n. sp.

\section{Paraleptolepis wiedenrothi $\mathbf{n} . \mathbf{s p}$.}

Figs 3-12

Diagnosis: As for genus.

Holotype: MB. f.7612, nearly complete specimen.

Type locality and age: Salzgitter-Haverlahwiese, SW of Braunschweig, Germany (Fig. 1): Early Jurassic, Toarcian.

Etymology: The specific name refers to $\mathrm{Mr}$. Kurt Wiedenroth, Garbsen, who collected the specimen and kindly deposited it in the Museum für Naturkunde, Berlin, for study.

Description: An elongate teleostean fish of about $140 \mathrm{~mm}$ total length (TL) and about $112 \mathrm{~mm}$ standard length (SL) (Fig. 3). The fish has a large head of about $30 \%$ in SL. The predorsal length is $57 \%$ SL; the prepelvic length is about $55 \% \mathrm{SL}$; and the preanal length $75 \% \mathrm{SL}$. The maximum depth of the body is behind the cleithrum, and this depth is relatively constant to the dorsal fin insertion. 


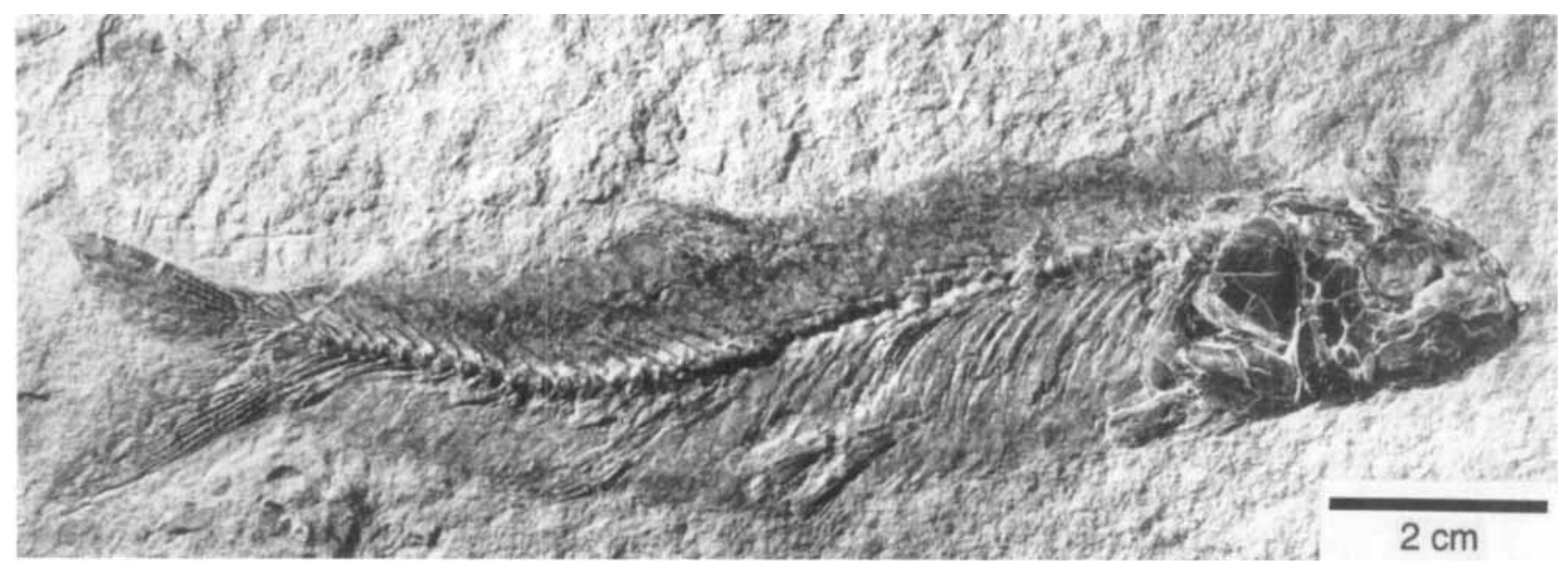

Fig. 3. Paraleptole ois wiedenthi n. gen. and n. sp. from the Early Jurassic of Saltgitter-Haverlahwiese, near Braunschweig. Lateral view of holotype MB. f.7612.

Head region: The cranial bones (Fig. 4A. B) are partially damaged. A few are covered by a thin layer of ganoine (e.g. maxilla); and with the exception of the maxilla and posterior part of the lower aw they lack ornamentation. The cranial roof includes anteriorly preserved ethmoidal fragments (e.g. mesethmoid). The largest bone is the pirietal [ = frontal of common terminology]: the bone is narrow anteriorly and broadens progressively posteriorly. and is expanded at the posterior margin of the orbit. Only a small segment of the supraorbital sensory canal is observed in the parietal; it runs closer to the medial margin of the bone than to the lateral one. A piece of the autosphenotic is preserved. The postparielal [= parietal of common terminology] is represented by remnants of fragmented bone. The perotic is also incompletely preserved. The bone interpreted as the extrascapula lies posterior to the pterotic and partially dorsal to the dorso-anterior margin of the opercle. Part of the sensory canal and two sensory pores are observed in the extrascapula. A fragment of a possible posttemporal bone is also preserved. The narrow anterior part of the parasphenoid. which has a groove dorsally. lies at the base of the braincase.

The circumorbital ring (Fig. 4A. B) includes remnants of the supraorbital(s) and of five infraorbital bones. Infraorbital 1 is incomplete: infra- orbital 2 is a moderately long and large bone. Infraorbital 3, at the postero-ventral corner of the orbit. has a well developed postero-ventral expansion that reaches the anterior margin of the preopercle. Infraorbital 4 is small and appears more square. There are remnants of what could be a small infraorbital 5 above infraorbital 4. The region occupied by the dermosphenotic is damaged. The area between infraorbitals 3-5 and the opercular bones is occupied by two suborbitals. The slightly squarish dorsal suborbital (sob1) is partially covered by the posterior magins of infraorbitals 4 and 5, whereas the ventral suborbital (sob2), which is slightly elongate, is posterior to infraorbitals 3 and 4 and anterior to the dorsal limb of the preopercle. There is no doubt that two suborbitals are present; they are separated by a suture, and in addition, the surface texture of the two bones follows different directions. There is a very small space left at the anteroventral corner of the dorsal suborbital; consequently, if there was an "accessory" suborbital, it was very small. The two incompletely preserved sclerotic bones are oriented anterior and posterior to the eyeball.

The upper jaw (Fig. 4A, B) is broken and represented by the premaxilla, the posterior part of the maxilla, supramaxilla 2 and a piece of supramaxilla 1 . The premaxilla has a long, well-developed ascending process (Fig. 4B) and a few

Fig. 4. Paraleptole wis wiedenrothi n. gen. and n. sp. Head and pectoral girdle and fin. in lateral vicw. A. Photograph of MB. 1.7612. B. Line dawing of the head and pectoral girdle and fin. Small pieces of the snout and of the left maxila that are placed around the parasphenoid are not illustrated. Oblique lines represent broken areas.

asp. autosphenoti $:$ b.io5. broken infraorbital 5; cl. cleithrum: exc". probable extrascapula: hy. hyomandibula; io1-4, infraorbital bone 1-4: iof - piece of interopercle: l.de. left dentary: mx. maxilla: op. opercle: pa[= fr] parietal bone [so-called frontal bonc]: par. anteri s portion of parasphenoid: pec.f. pectoral fin: pmx. premaxilla: pop. preopercle: pt. pterotic; ptt:, probable posttemporal: r.de, right dentary: sc. scale; scl. supracleithrum; scl.b. sclerotic bones; smx1-2, supramaxilla 1-2; sob1-2, suborbital bone 1-2: sop. suhopercle: sor.c. piece of supraorbital canal: sup. pieces of supraorbital bone. 

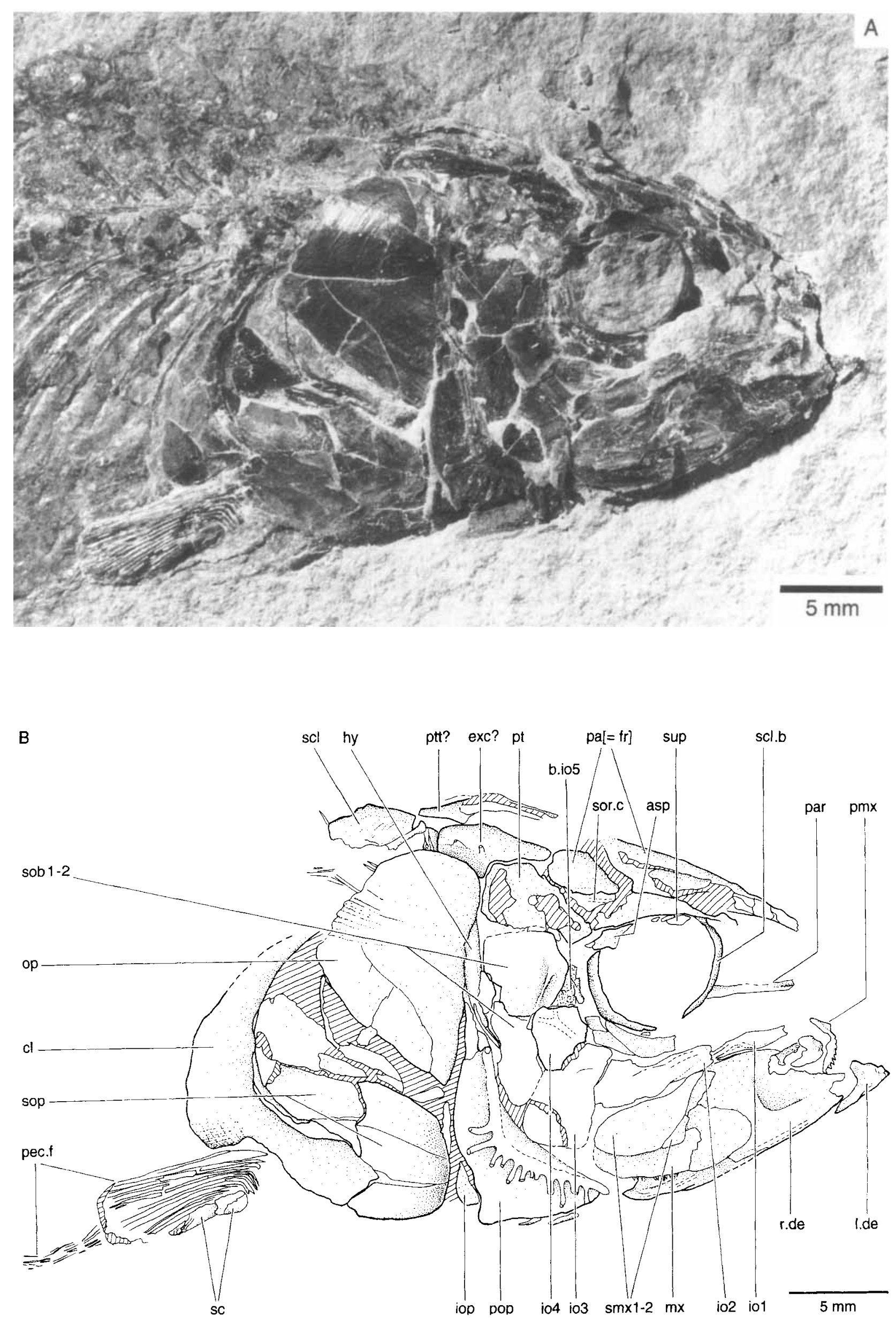
conical teeth in the oral margin. The surface of the maxilla is :overed by a thin layer of ganoine with small tuhercles and ridges. The posterior margin of the maxilla is rounded; the ventral margin carries small conical teeth. Supramaxilla 2 overlaps the postero-dorsal region of the maxilla; supramaxilla 2 is slightly oval with an elongate antero-dorsal process that overlaps supramaxilla 1. Because of the position of the preserved bones, we suggest that supramaxilla 1 was an elong tte bone overlapping the anterodorsal region of the maxilla.

The lower jaw (Fig. 4A. B) is deep and heavily ossified. Laterally. it consists of dentary and angular. It is unl nown whether the angular, articular, and retroarticular are fused or not. Most of the jaw is formed by the dentary. Unfortunately. the oral margin of the dentary is damaged, but due to the slape of the bone it is possible to suggest that the oral margin ascended abruptly. from a very rarrow mandibular symphysis. producing a high coronoid process. Due to poor preservation, we cannot establish if the dentary had a 'leptolepid' notch or not. The dorsal margin of the angular, seen medial to the maxilla and supramaxilla 2, also ascends abruptly to form part of the coronoid process. The short postarticular process ends $\mathrm{n}$ a sharp tip. The mandibular canal runs close to the ventral margin of the jaw. The posterior opening of the mandibular canal is not visible laterally; therefore, we interpret it as having a postero-medial position.

The articulation between the lower jaw and quadrate lies below the posterior region of the orbit. The bones of the palatoquadrate (e.g.. autopalatine, demopalatine) are not seen because they are cove ed by other lateral head bones. or they are not preserved. A small section of the hyomandibula is present between suborbital 1 and the opercle.

The lower part of the hyoid arch, branchiostegal rays, and gular region are not preserved.

The opercu ar bones (Fig. 4A, B) are large elements. The preopercle (Figs $4 \mathrm{~B}, 5$ ) is broad and slightly subtri ingular. A notch is present at the posterior margin of the preopercle as in "pholidophorids' and proleptolepids. but in the latter the notch is rore pronounced. The ventral limb of the bone is short; the dorsal limb is missing its dorsalmost $\mathrm{p}_{\mathrm{c}} \mathrm{rt}$, consequently. it is not possible to establish it; height. There is no evidence of a suprapreopercle. The preopercular sensory canal is enclosed in a bony tube that runs close to the anterior margin of the bone. There are 12 sensory tubules of varying lengths. most of which do not reach the postcro-ventral margin of the preopercle. Sensory tubules are not present in the upper part of the dorsal limb.

The opercle (Fig. 4A, B) has a round dorsal margin which is narrower than the oblique ventral margin of the bone. Much of the posterior margin is finely crenulated. The articular facet for the hyomandibula is not visible. The large subopercle, partially broken. is greatly expanded posteriorly and ventrally. Both the opercle and the subopercle produce a kind of triangle with the broadest part at the ventral level of the subopercle.

Vertebral column and associated bones: There are ca. 44 vertebrae including preural centrum 1. Several anterior abdominal vertebrae are hidden by the opercle (we assume for them a count of four because of the tips of the neural spines are visible and the approximate length of the braincase). It is difficult to identify the precise transition from abdominal to caudal vertebrae; but apparently 19 caudal vertebrae are present. The abdominal centra are slightly constricted and ring-like. Each is formed by a moderately thick chordacentrum surrounded by a thin, smooth autocentrum. One of the abdominal vertebra shows a broad parapophysis fused to the autocentrum (Fig. 6). Ventrally, the parapophysis has a cavity for articulation of the

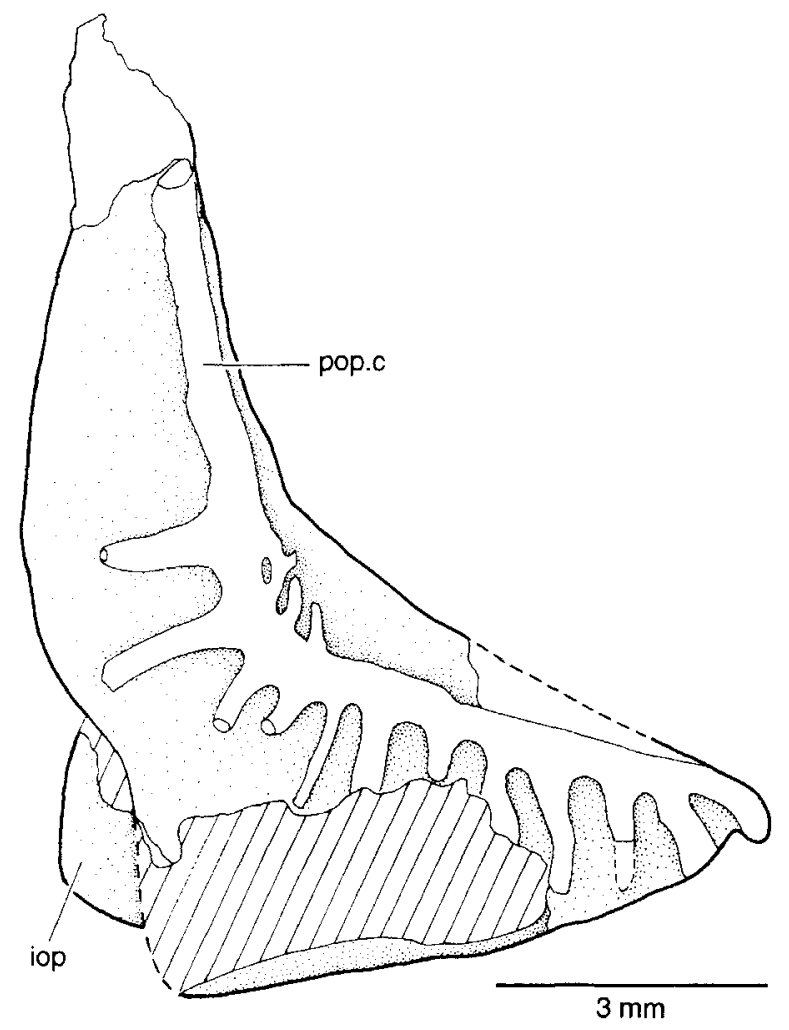

Fig. 5. Paraleptolepis wiedenrothi n. gen. and n. sp. Preopercle in lateral view (MB. f.7612).

iop. interopercle: pop.c, preopercular sensory canal. 

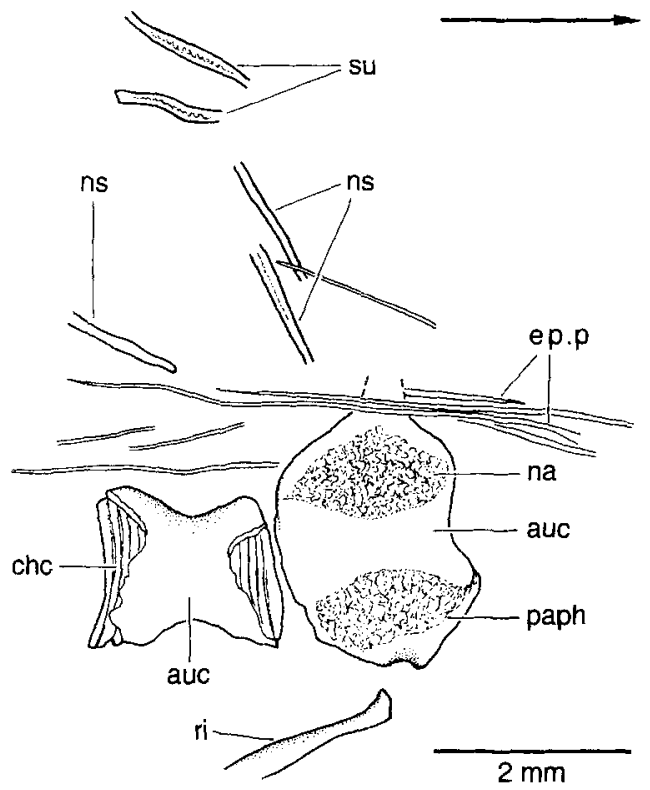

Fig. 6. Paraleptolepis wiedenrothi $\mathrm{n}$. gen. and n. sp. Abdominal vertebrae and associated elements in lateral view. Note that the chordacentrum is visible where the autocentrum is broken. Arrow points anteriorly.

auc, broken autocentrum; chc, chordacentrum; ep.p, epineural process; na, neural arch; ns, broken neural spine; paph, parapophysis; ri, rib; su, supraneural. rib. Abdominal neural arches are mainly incomplete; but it is still possible to observe that the neural spines are thin, elongate, and do not reach the dorsal margin of the body. The paraphophyses, like the neural spines, appear to have contained secondary cartilage in different degrees of chondrification.

The ribs are elongate, but they do not reach the ventral margin of the body. They are broader proximally and narrower distally. A thin core of cartilage was evidently present along the center of each rib (evidenced by spaces in the bone). The posterior ribs are shorter than the anteriormost ones.

In the caudal region, neural and haemal arches of the anteriormost caudal vertebrae fuse to their autocentra (Figs 7,8). Each arch is on the anterior half of its centrum. The anterior caudal vertebrae (Fig. 7) have spines projecting from the haemal arches. It is unclear whether the halves of each arch remain unfused medially or not. At least, the last two ribs are associated to the short haemal spines. The following two haemal arches also bear short spines and are asso-
Fig. 7. Paraleptolepis wiedenrothi $\mathrm{n}$. gen. and $\mathrm{n}$. sp. Last abdominal and anterior caudal vertebrae and associated elements in lateral view. Note that the chordacentrum is visible where the autocentrum is broken. Arrow points anteriorly. a.pt, anal pterygiophore; auc, autocentrum; b.ha, broken haemal arch; che, chordacentrum; ha, haemal arch; hs, haemal spine; ith, interhaemal bone; na, neural arch; ns, neural spine;

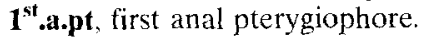

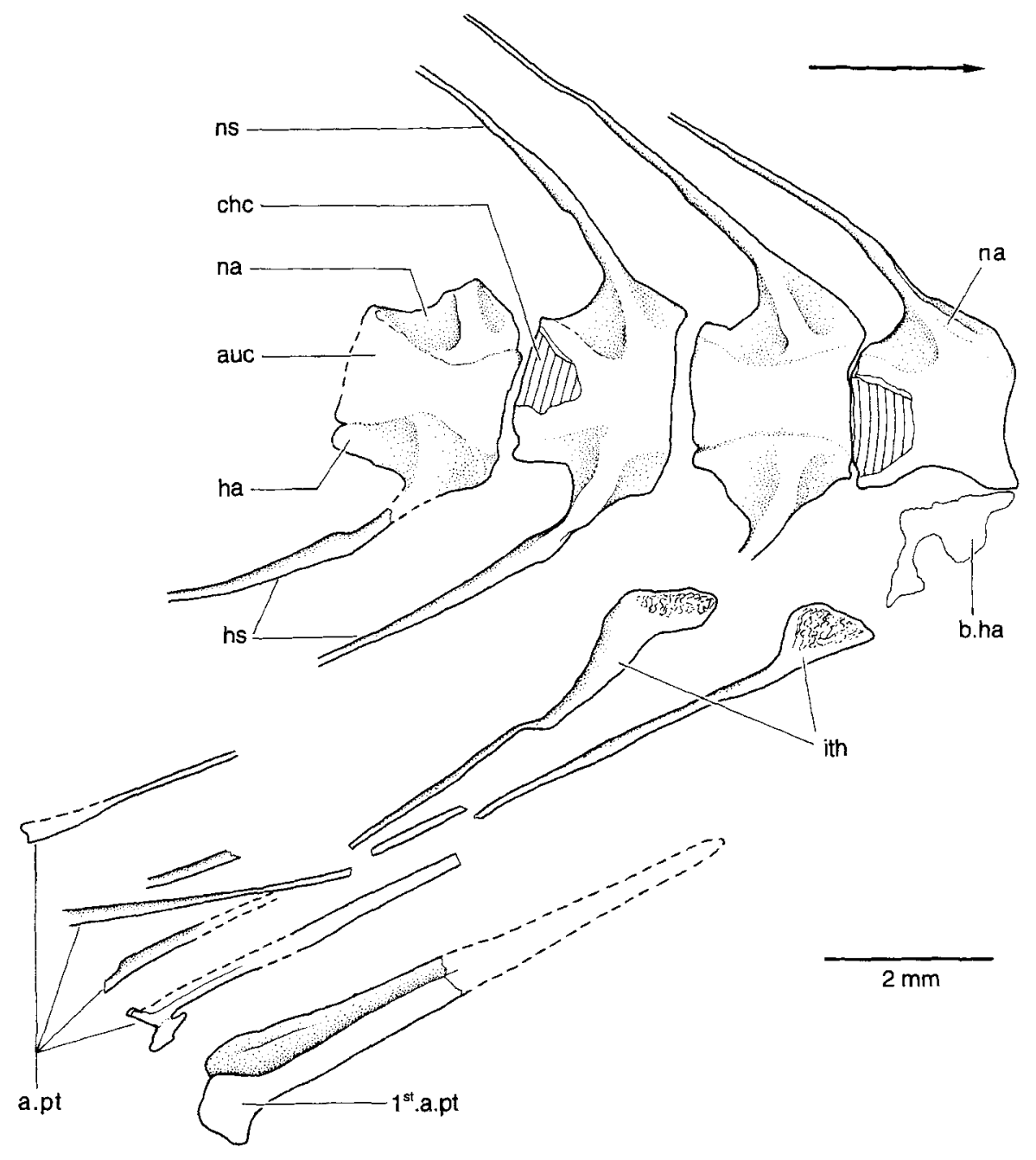




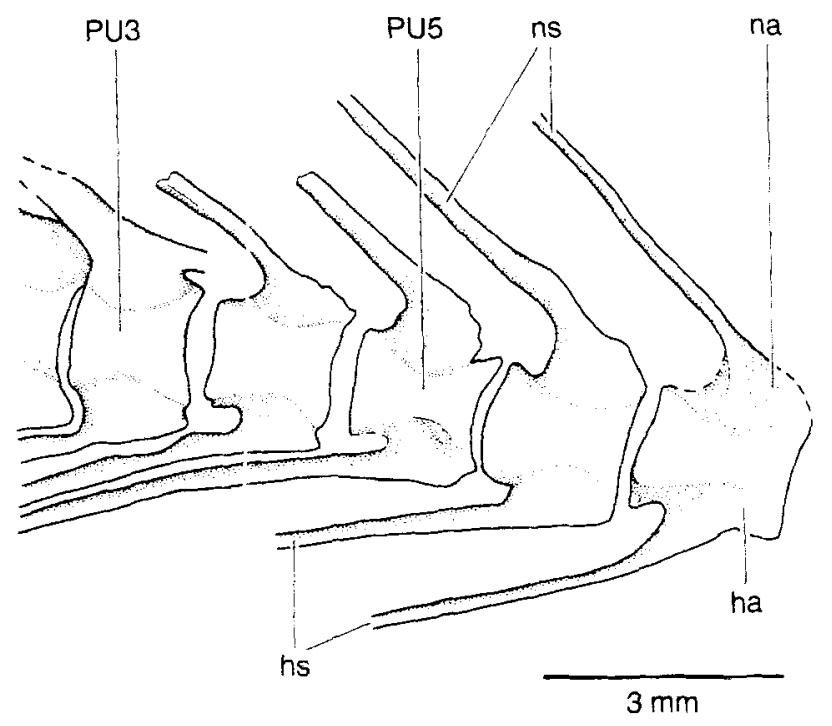

Fig. 8. Paraleptolpis wedenrothi n. gen. and n. sp. Posterior caudal vertebrac and associated elements in lateral view.

ha. haemal arch: hs. haemal spine: na. neural arch: ns. neural spine: PU3-5. preural centrum 3-5.

ciated with two interhaemal bones. The following haemal spines are long and narrow. but do not reach the ventral margin of the body. The haemal spines of the posterior caudal vertebrae are strongly inclined to the body axis (Fig. 8).

Series of s spraneural and epineural bones are present. The supraneural series is incompletely preserved; the first supraneural is broader than the more posterior ones, a condition observed in other primitive teleosts. The posteriormost supraneurals are slightly sigmoidal and extend between the first dorsal pterygiophores. The supraneurals evidently retained a core of secondary cartilage inside the bone.

The epineurals (Fig. 6) are long. thin processes that extend laterally at least to five or six neural arches. Each epineural is not fully ossified. probably because it contained secondary cartilage internally. The last epineural is located below the posterior resion of the dorsal fin and corresponds to in abdominal vertebra. Epipleural bones are arsent.

Paired girdles and fins: The pectoral girdle and fin (Fig. 4A, B) are incompletely preserved. Part of a possible posttemporal and an incomplete supracleithrum are preserved. The cleithrum is a very large bone with its anterior margin procuced into a markedly round curve. unlike the condition observed in Leptolepis coryphaenoides and proleptolepids. The dorsal margin is obliquely directed toward the cranium, and narrower than the middle section of the bone. Unfortunately. the antero-ventral limb of the cleithrum is incompletely preserved. so it is not possible to establish the bone's broadness. It is not clear whether or not a patch bearing teeth like that described and illustrated for Leptolepis coryphaenoides by Arratia \& Schultze (1990: fig. 10D. E) is present.

There are 11 or 12 pectoral lin rays. They have long unsegmented bases and are finely branched and segmented distally. A pectoral axillary process seems to be absent, but slightly modified elongate scales are present near the pectoral fin insertion.

The pelvic girdles are formed by two triangular pelvic bones with slightly truncated anterior tips. The posterior region of each pelvic plate evidently contained large areas of secondary cartilage or chondroid bone. Pelvic radials are not visible in our material. There are 11 or 12 pelvic rays in each fin, which have long bases and are finely branched and segmented distally. A pelvic axillary process is present on the leading ray, formed by a single, elongate, and thick bony element (Fig. 9A). The process is about $50 \%$ of the length of the leading ray.

Unpaired fins: The dorsal fin is poorly preserved. The fin insertion is positioned slightly in front of the insertion of the pelvic fin. There are about 14 rays, all of which are severely da-
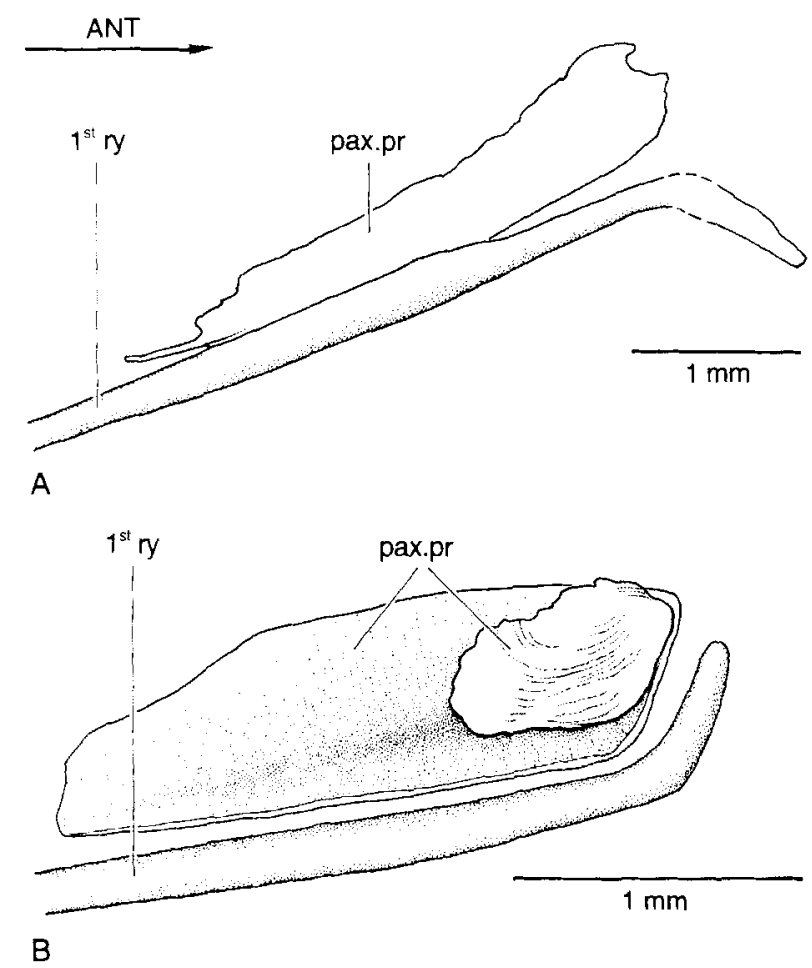

Fig. 9. Pelvic axillary process. A. Paraleptolepis wiedenrothi n. gen. and n. Sp. (MB. 1.7612). B. Leptolepis opercularis (BGHan 1957-2). Note that the pelvic axillary process is formed by a bony elcment covered by small scales.

ANT, anterior: pax.pr, pelvic axillary process: $1^{\text {st }} \mathbf{r y}$, first pelvic ray. 


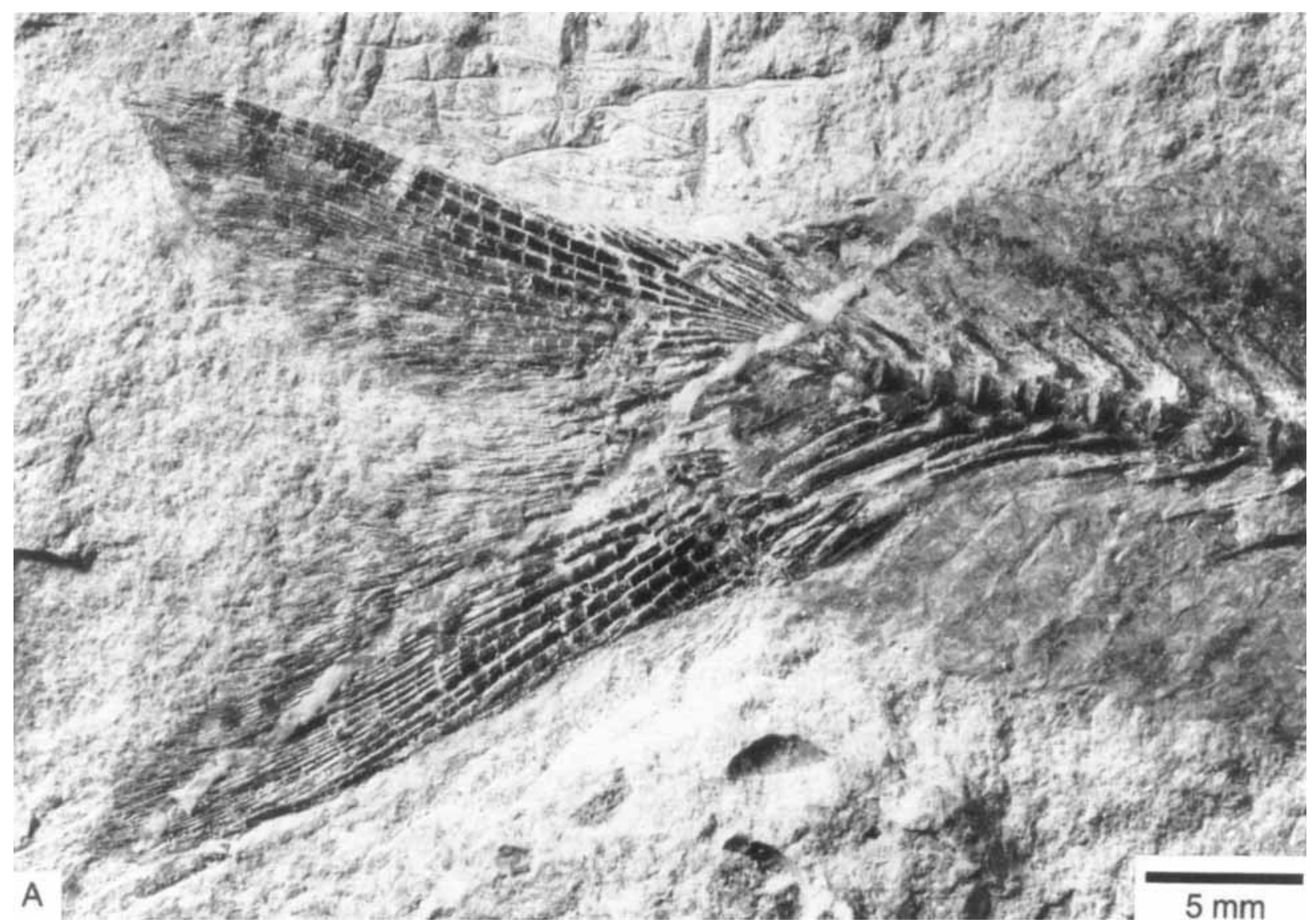

Fig. 10A

maged. The first pterygiophore is bifurcated, but it is unclear whether it has two or three anteroventral processes. There are a few pterygiophores preserved.

The anal fin has two small simple rays and seven principal rays preserved. The first anal pterygiophores (Fig. 7) are the longest of the series. The total number of rays is unknown.

Unfortunately, a broken area crossing the caudal fin damaged some of the fin structures. The fin (Fig. 10A, B) is clearly forked, with the ventral lobe slightly longer than the dorsal lobe. The marginal branched rays are the longest, whereas the middle rays are very short. The caudal fin is supported by the neural spine of preural centrum 1, epurals, uroneurals, hypurals, and four or five haemal spines belonging to preural centra $5-1$.

The preural vertebrae (Figs 10A, B, 11) are thin and delicate. The neural and haemal arches are fused to a thin, smooth autocentrum. Large remnants of secondary cartilage and probably chondroid bone are retained inside the arches, the neural and haemal spines, and the hypurals. An anterior process is present on the haemal arch of preural centrum 1. The neural and haemal arches are broad and slightly rounded. The distal ends of neural spines are slightly expanded, but not as expanded as in Leptolepis coryphaenoides (Arratia 1991: fig. 7). The haemal spines of preural centra 5-4 are narrow and reach the bases of the precurrent ventral rays. In contrast, the haemal spines of preural centra $3-2$ and the parhypural are thick and broader than the more anterior caudal spines. Preural centrum 1 (Figs 10B, 11) appears to bear a long neural spine (although somewhat obscured by the broken area), apparently as long as the neural spine of preural centrum 2. The neural arch of preural centrum 1 is not laterally fused to the autocentrum. The parhypural is slightly broader than the haemal spine of preural centrum 2 .

The ural centrum $1+2$ (Figs 10B, 11) is longer than the preural centra 3-1. The bases of hypurals 1 and 2 are fused to the thin autocentrum of ural centrum $1+2$ like the condition observed in Leptolepis coryphaenoides (Arratia 1991: figs 7, 8a, b). A (displaced) neural arch and short spine belongs to the ural centrum $1+$ 2; this neural arch is autogenous.

Only two hypurals are preserved. Hypural 1 is larger and broader than hypural 2. It bears an anterior process proximally. Hypural 1 has still large remnants of secondary cartilage and prob- 


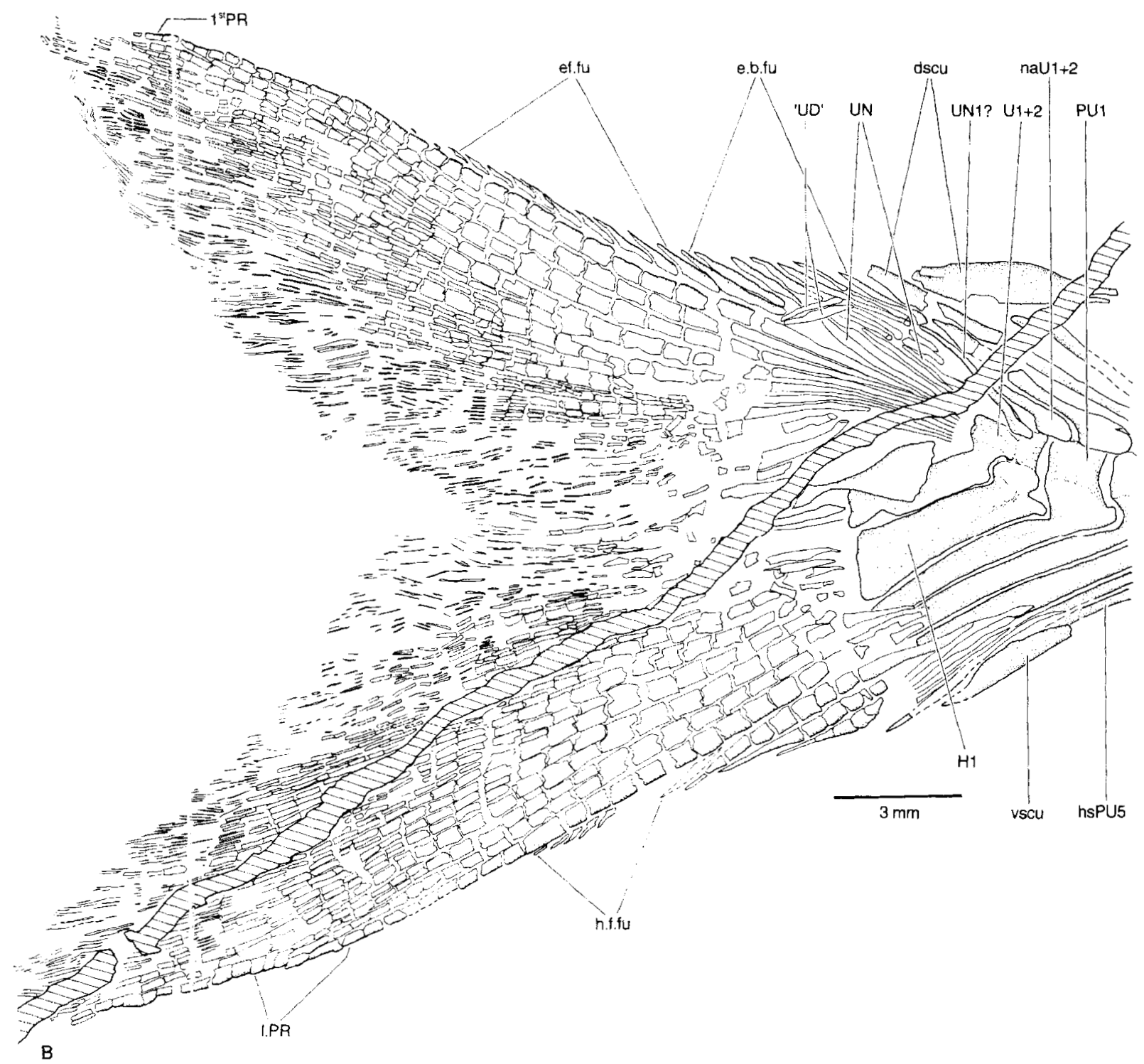

Fig. $10 \mathrm{~B}$

Fig. 10. Paraleptolepis wiedemrothi n. gen. and n. sp. Caudal skeleton as preserved in lateral view.

A. Photograph of MB. f.7612. B. Line drawing of the same specimen. Oblique lines represent broken areas.

e.b.fu, cpaxial basal fulcra: e.f.fu. epaxial fringing fulcra: dscu. dorsal caudal scute; H1 hypural 1; h.f.fu, hypaxial fringing fulcra: hsPU5. hacnal spine of preural centrum 5 ; naU1 +2 . neural arch of ural centrum $1+2$; PU1, preural centrum 1 ; 'UD'. urodermal: $\mathbf{U} \mathbf{1}+\mathbf{2}$. first ural centrum interpreted as result of fusion of ural centra 1 and 2 ; UN, uroneural; UN1?

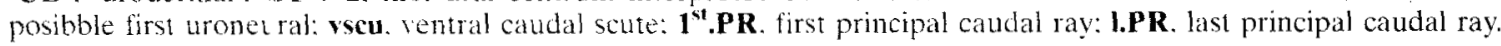

ably chondroid hone at its base and has an anterior process. The distal tips of hypurals 1 and 2 are filled with cartilage in different stages of chondrification cr ossification.

The total number of epurals is unknown. Remnants of two na:row epurals are preserved. The uroneurals (Fig. 11) are displaced: five elongate. narrow elements are observed. The first uroneural (UN1?) does not reach the preural centrum 1: in addition. remriants of uroneural(s) are not observed on the lateral surface of the centra. This is similar to the pattern in Proleptolepis furcata (Nybelin 1974: text-fig. 19).
Two narrow, moderately elongate 'urodermals' (Fig. 10B) are present. They are displaced from their common position (lateral to the first two principal caudal rays).

Two dorsal scutes (Fig. 10B) are present. The more dorsal is elongate and larger than the other (incomplete) scute, and subdivided anteriorly and posteriorly. There is one elongate and narrow ventral scute.

There are about seven epaxial basal fulcra, nineteen $(10+9)$ principal caudal rays, about five segmented ventral precurrent rays, and a short hypaxial fringing fulcra (Fig. 10A, B). A reduced 


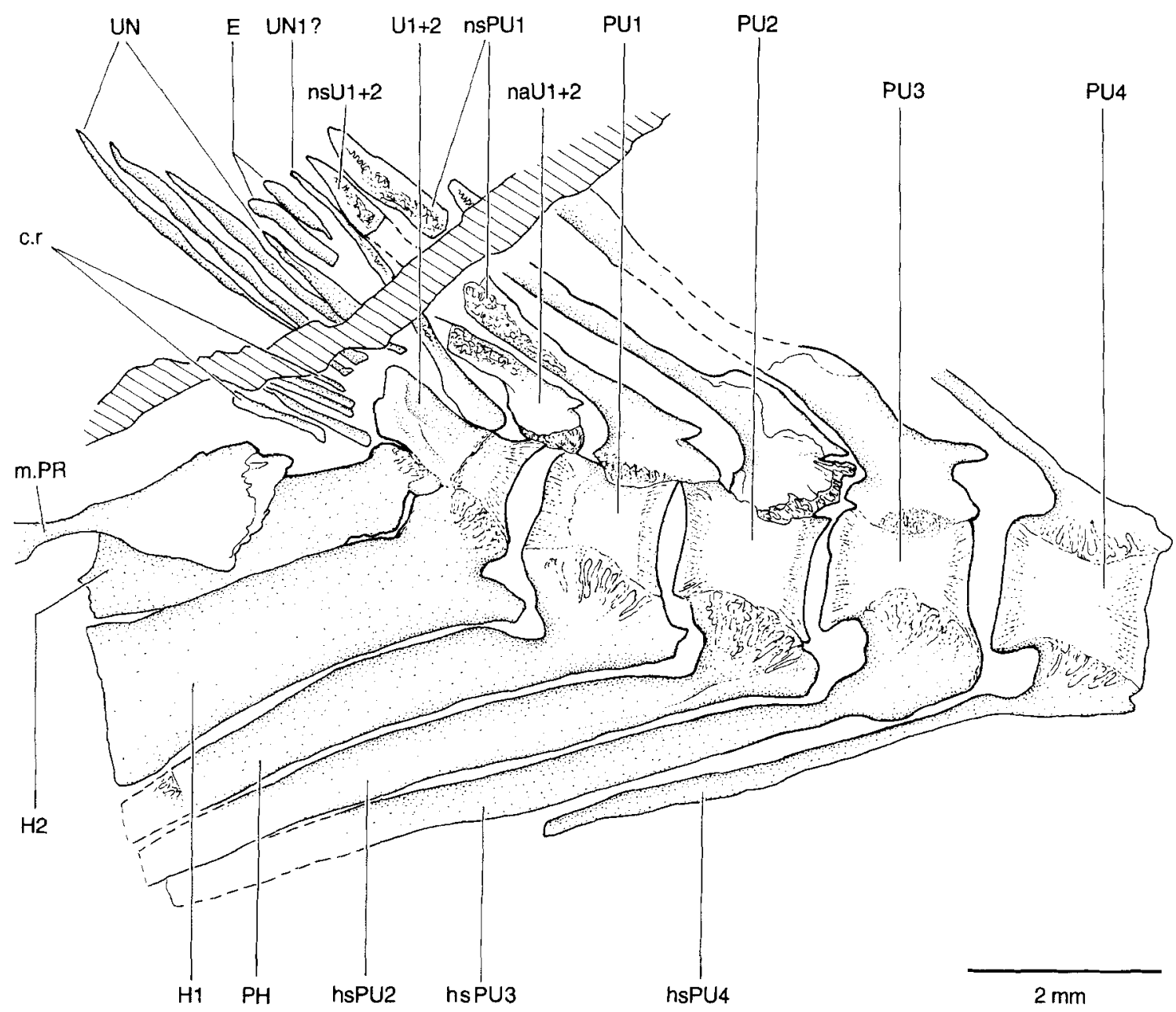

Fig. 11. Paraleptolepis wiedenrothi $\mathrm{n}$. gen. and n. sp. Enlargement of caudal endoskeleton in lateral view (MB. f.7612). Oblique lines represent broken areas.

c.r. bases of caudal fin rays; E, epural; H1-2, hypural 1-2; hsPU2-4, haemal spine of preural centrum 2-4: m.PR. middle principal caudal ray; nsPU1, broken neural spine of preural centrum 1; naU1 + 2, neural arch of ural centrum $1+2$ : nsU1 + $\mathbf{2}$, broken neural spine of ural centrum $1+2$; PH, parhypural; PU1-4, preural centrum $1-4 ; \mathbf{U 1}+\mathbf{2}$. first ural centrum interpreted as result of fusion of ural centra 1 and 2; $\mathbf{U N}$, uroneural; $\mathbf{U N 1}$ ?, possible uroneural 1 .

epaxial ray and segmented dorsal precurrent rays are absent in this taxon. The expanded base of one of the innermost principal caudal ray is preserved and partially covers hypural 2 . It is unclear whether the inner principal caudal rays of the dorsal lobe have sharp dorsal processes at their bases. The segmentation of the principal caudal rays is mostly straight; however, it is slightly step-like in outline in some segments of the inner principal rays. The first and last principal caudal rays are segmented, whereas the innermost principal rays are segmented and branched distally.

The gentle dorsal flexure of the vertebral column begins at preural centrum 3 .

The trunk is covered with large, thin, oval and round cycloid scales. They have many circuli around the focus. Radii are absent. The scales seem to be identical to that illustrated by Schultze (1966: fig. 39) for Leptolepis coryphaenoides. They are not covered with a layer of ganoine.

\section{Comparison with other basal teleosts}

Our first impression of the fish was that it was a large Leptolepis coryphaenoides, a common teleost from the Lower Jurassic of Germany and other European localities. However, closer examination revealed that behind the overall similarity, there are significant differences between it and $L$. coryphaenoides (and also $L$. normandica from the Upper Lias of Normandy and Gloucestershire). A comparison between Leptolepis, Proleptolepis and Paraleptolepis n. gen. is provided below.

\section{Leptolepis coryphaenoides}

The most recent diagnosis of the genus Leptolepis is that of Nybelin (1974: 183) and it is based on a series of features such as "Premaxillary rather large. Suborbital very broad, no "acces- 
sory" suborbital. Preoperculum without a notch in its posteric margin. Vertebral centra slightly constricted beny cylinders. Caudal skeleton with three epurals, eight to nine hypurals and six to seven uroneurals. anteriorly reaching the second or third preural centrum. A few fringing fulcra on the dorsal margin of the caudal fin."

An analysis of Nybelin's (1974) characters reveals that all of them are either ambiguous, or broadly distrituted and primitive among teleosts. For instance, a "rather large" premaxillary bone. An interpretation of the meaning of "rather large" is confusing. because the bone in Leptolepis coryphaenoides may be interpreted as small by comparison to other teleosts. The new fish has a small premaxilla. but its ascending process and the oral region are slightly longer than those in L. coryphaenoides (compare Figs 4B, 12A and 12B).

Leptolepis sensu Nybelin has one suborbital bone (Fig. 12B-D) which completely occupies the region between the dorsalmost infraorbitals. the pterotic, and preopercle. A similar pattern is also present in the so-called pholidophorids described and illustrated by Nybelin (1966) (Figure $12 \mathrm{~B}-\mathrm{C}$ are idcalized restorations of the head of Leptolepis: in contrast. Figure 12D closely follows the size and proportions of the bones. Note that the suborbital follows the anterior margin of the opercle in Figure 12B. C. whereas it overlaps the anterior margin of the opercle in Figure 12D). In contrast to Leptolepis. Paraleptolepis n. gen. has two suborbitals (Figs 4B. 12A). Among basal Jurassic teleosts. one small suborbital is found in Varasichthys and Bobbichthys from the Jurassic of Cliile (Arratia 1984. 1986. 1997). whereas other basal Jurassic teleosts such as Tharsis, Ascalabos. Cavenderichthys, Allothrissops, Pachythrissops and others lack a suborbital bone. An "accessory" suborbital bone is absent in Leptolepis and in the Paraleptolepis $\mathrm{n}$. gen.

The preopercle (Fig. 12B-D) of Leptolepis coryphaenoides and L. normandica has well-defined dorsal and ventral limbs: the bone is boomerang-shaped. In contrast. the bone is subtriangular in profile in Paraleptolepis n. gen. (see Figs 4A. B. 5. 12A). A notch at the posterior margin of the preoper le is missing in Leptolepis. However. a notch is observed in Triassic and Liassic 'pholidophorifcrms' from Europe (e.g.. Nybelin 1966. Zambelli 1975, 1986) and in Proleptolepis (Fig. 12D: Nyb lin 1974). A notch is present in Paraleptolepis 11. gen. (Figs 5, 12A). The notch is absent in other Jurassic basal teleosts such as Tharsis. Ascalabos. Cavenderichthys, members of the varasichthyid group and others (Arratia 1997). Additionally, the number of tubules of the preopercular sensory canal is higher in Leptolepis than in Paraleptolepis $\mathrm{n}$. gen. (compare Fig. 11A and 11B-D). Variation in the number of tubules of $L$. coryphaenoides has been described by Wenz (1968) and Nybelin (1974).

The centra of Leptolepis are slightly constricted bony cylinders, according to Nybelin (1974). The manner that the caudal centra were described and/or illustrated by Nybelin (1963: figs 9. 10), Patterson (1968: text-fig. 9) and Patterson \& Rosen (1977: fig. 33B) would correspond to the presence of chordacentra alone. In contrast. the centra of $L$. coryphaenoides (and of Paraleptolepis n. gen.) are ring-like centra each formed by a chordacentrum surrounded by a thin bony autocentrum (Schultze \& Arratia 1989: fig. 6A. B. Arratia 1997: fig. 89A-C). If there is any constriction of the notochord, it is very slight. The surfaces of the autocentra in Leptolepis and Paraleptolepis n. gen. are smooth, lacking crests and fossae that are present in more advanced teleosts.

Some of the diagnostic features of Leptolepis, based on the caudal skeleton, cannot be compared with that of Paraleptolepis n. gen. because of poor preservation (e.g., number of epurals, uroneurals, and hypurals). The first uroneurals in Leptolepis reach the second or third preural centrum anteriorly (see Arratia 1991: fig. 7). In Paraleptolepis n. gen. there is no remnant of uroneural(s) lying on the preural centra; therefore, our interpretation is that the first uroneural does not extend anteriorly. A series of fringing fulcra is present on the dorsal margin in Leptolepis; in contrast both epaxial and hypaxial fringing fulcra are present in Paraleptolepis $\mathbf{n}$. gen. and in Teleosts sp. 1 from the Late Jurassic (Oxfordian) of Chile (Arratia 1991: fig. 3). The fringing fulcra are moderately long in the new fish, not reaching the distal tips of the leading principal caudal rays: in contrast. epaxial and hypaxial fulcra are very long in the Chilean Teleost sp. 1.

In addition to the above mentioned differences. Paraleptolepis n. gen. differs from Leptolepis coryphaenoides (and L. normandica) in several other features. For instance:

1) The preserved parietal bone in Paraleptolepis $\mathrm{n}$. gen. is large and projects ventrolaterally. In contrast. the bone is smaller in Leptolepis (and also in Proleptolepis) (compare Fig. $11 \mathrm{~A}$ and $11 \mathrm{~B}-\mathrm{E}$ ).

2) The shape of the opercle and subopercle differs between Leptolepis and Paraleptolepis $\mathrm{n}$. 

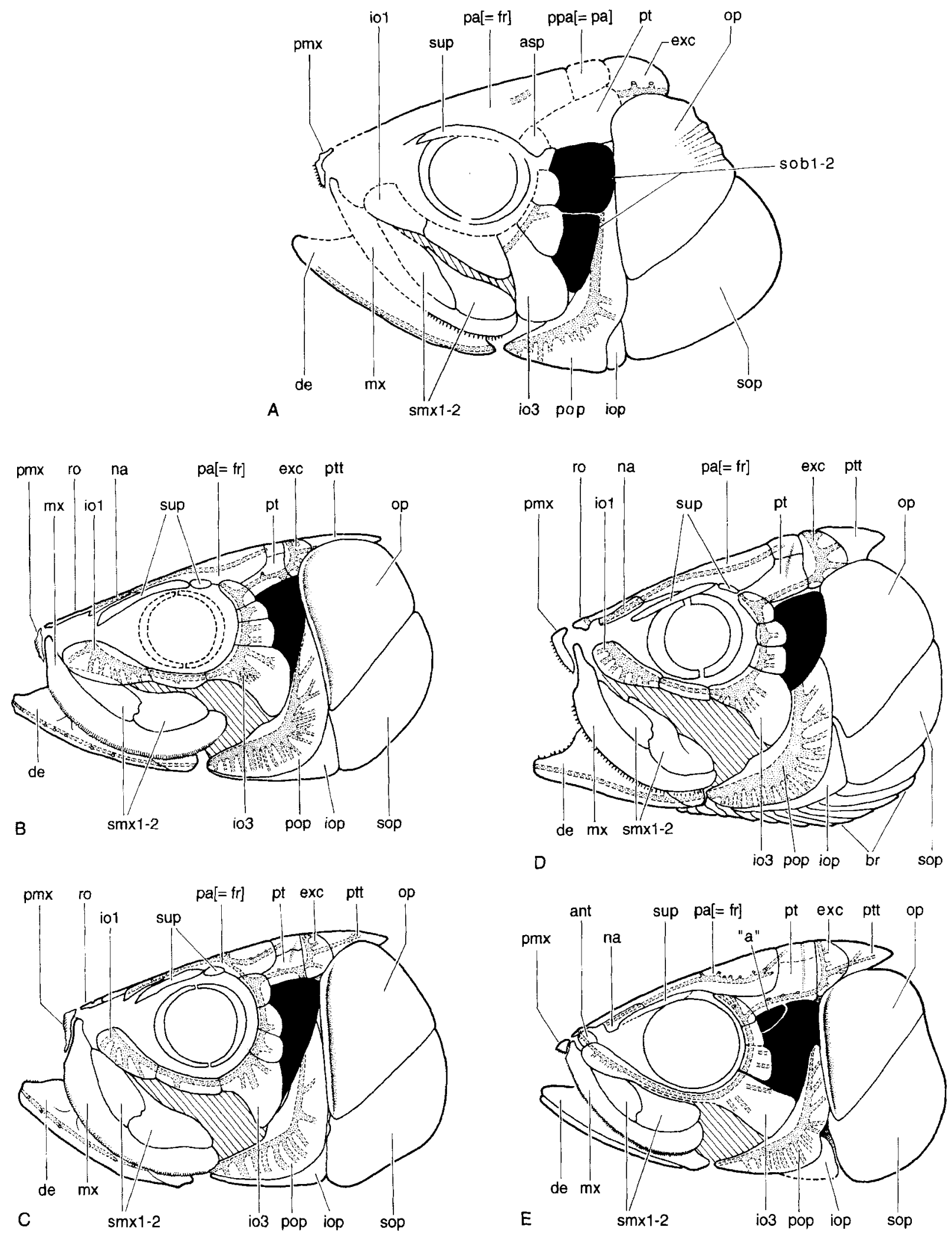

Fig. 12. Restorations of heads in lateral view. Suborbital region in black. A. Paraleptolepis wiedenrothi n. gen. and n. sp. (restoration reversed to the left). B. Leptolepis normandica (after Nybelin 1974: text-fig. 1). C. Leptolepis coryphaenoides (after Nybelin 1974: text-fig. 4). D. Leptolepis coryphaenoides (after Arratia 1996: fig. 1D). E. Proleptolepis furcata (after Nybelin 1974: text-fig. 15).

"a", accessory suborbital; ant, antorbital; asp, autosphenotic; br, branchiostegal rays; de, dentary; exc. extrascapula; iol-3. infraorbital bone 1-3; iop, interopercle; mx, maxilla; na, nasal bone; op, opercle; pal= fr], parietal [ $=$ frontal of common terminology]; pnix, premaxilla; ppa[= pa], postparietal [= parietal of common terminology]; pt, pterotic; ptt, posttemporal; ro. rostral bone; smx1-2, supramaxilla 1-2; sop, subopercle; sup, supraorbital bone. 
gen. (compare Figs 4A. B. 11A and Fig. $11 \mathrm{~B}-\mathrm{D})$.

3) Acid preparation of specimens of Leptolepis coryphaensides reveals the presence of at least four interhaemal bones (Arratia 1996: fig. 1D). Two interhaemal bones are observed in Paraleptolepis n. gen. (Fig. 7). The condition is unknown in Pholidophorus and Proleptolepis.

4) The shape of the cleithrum is very distinctive in Paraleptolepis n. gen., due to its strong curvature: the dorsal limb of the cleithrum of Leptolepis coryphaenoides is almost straight.

5) A pelvic axillary process (Fig. 9A. B) is present in both Leptolepis coryphaenoides (Arratia 1997. 1999) and Paraleptolepis n. gen. In both taxa the process is formed by bone. but the bone in L. coryphaenoides has a slightly curved surface to accomodate modified small scales. Modified scales are not associated to the flat. soft surface of the pelvic axillary process of Paraleptolepis n. gen.

6) The neural spines of preural centra of Leptolepis coryphaenoides are broad and slightly expanded distally (Arratia 1991: fig. 7. Arratia 1996: fig. 1D). while the spines of Paraleptolepis n. ger. are narrower (Figs 8.10A. B).

7) The neural spine of preural centrum 1 in Leptolepis coryphaenoides is shorter than those of preceding centra (Arratia 1991: figs 7, 8a. b): ir contrast, the spines are of similar size in Paruleptolepis n. gen. (Fig. 11).

8) Ural centrum $1+2$ in Leptolepis coryphaenoides may have a broad. small arch fused to the dorsal margin of the centrum: this arch has a very short neural spine (Arratia 1991: figs $7,8 \mathrm{a}$. o). In contrast, the neural arch is autogenous in Paraleptolepis n. gen. and has an elongato spine. The neural spine of ural centrum $1+2$ is shorter than that of preural centrum 1.

9) The segmentation of most principal caudal rays of Leptolepis coryphaenoides is steplike: it is a combination of straight and steplike segmeritation in Paraleptolepis n. gen.

10) Leptolepis coryphaenoides has one dorsal and one ventral caudal scute. whereas Paraleptolepis $\mathrm{r}$. gen. has one ventral but two dorsal scutes.

11) The maximum length of Leptolepis coryphaenoides and $L$. normandica is about $80 \mathrm{~mm}$. Paraleptolepis n. gen. is longer, about $140 \mathrm{~mm}$ in rotal length.

The morphological differences found between Leptolepis coryphaenoides (and in L. normandi- $c a$ which is almost identical to $L$. coryphaenoides) and Paraleptolepis n. gen. (which possess several uniquely derived morphological features) justify placing the fish described here in a new genus and species.

\section{Proleptolepis spp.}

Nybelin (1974) erected the new genus Proleptolepis to contain three species from the Early Jurassic of Europe (and an additionally undescribed Proleptolepis sp.). Later, small teleosts identified as indeterminate proleptolepids have been reported from the Liassic (Sinemurian) of Chile by Arratia (1987) and Arratia and Schultze (1999).

The diagnosis of the genus Proleptolepis is very similar to that of Leptolepis with the following exceptions. Proleptolepis has a rather broad suborbital and an "accessory" suborbital bone (Fig. 12E) at the anterodorsal corner of the suborbital. The preopercle has a notch at its posterior margin. The caudal skeleton has more epurals (4) and more hypurals (about 11). There are about six uroneurals, the two anterior ones reaching anteriorly the preural centrum 1 . Numerous fringing fulcra on both the dorsal and ventral margins of the caudal fin (Nybelin 1974: 80).

Proleptolepis has a rather triangular premaxilla. similar to that present in Varasichthys ariasi among Jurassic teleosts (Arratia 1981), lacking a defined ascendent process. In contrast, the premaxilla has an elongate ascending process and a well-defined oral process in Leptolepis and Paraleptolepis n. gen. (compare Fig. 12E and Figs 4B and $11 \mathrm{~A}-\mathrm{D}$ ). The ascending process is comparatively longer in Paraleptolepis n. gen.

Paraleptolepis n. gen. and Proleptolepis differ in that Paraleptolepis n. gen. has two distinct suborbitals and lacks an "accessory" suborbital, whereas Proleptolepis has one suborbital and a small "accessory" suborbital (compare Figs 4B, $12 \mathrm{~A}$ and 12E). An "accessory" suborbital is also present in Pholidophoroides (Nybelin 1966: textfigs 9, 12).

In Proleptolepis the preopercle has long dorsal and ventral limbs, and the bone has a shape similar to that of Leptolepis. In contrast, the bone is subtriangular in profile in Paraleptolepis $\mathrm{n}$. gen. (compare Fig. 12A and 12B-E). A well-defined notch (Fig. 12E) is present at the posterior margin of the preopercle in Proleptolepis, as well as in Triassic and Liassic 'pholidophoriforms' (Nybelin 1966, Zambelli 1975, 1986). A similar notch (Figs 4A, B, 5) is present in Paraleptolepis 
n. gen. Paraleptolepis n. gen. has fewer preopercular sensory canal tubules

A large subopercle (Fig. 12A) with a greatly expanded posterior region is present in Paraleptolepis $\mathrm{n}$. gen. The subopercle is not greatly expanded posteriorly in Pholidophorus, most specimens of Proleptolepis and in Leptolepis (Fig. 12B-E). A moderately large posterior expansion of the subopercle is found in some specimens of Proleptolepis megalops (Nybelin 1974: text-fig. 20).

Paraleptolepis n. gen. and Proleptolepis share the primitive character of possessing both epaxial and hypaxial fringing fulcra on the caudal fin. The difference is in the length: the series of fringing fulcra are longer on Proleptolepis. Proleptolepis, Leptolepis, and Paraleptolepis n. gen. share the presence of an elongate first ural centrum, interpreted here as resulting from the fusion of ural centra 1 and 2 (in polyural terminology).

Paraleptolepis n. gen., Proleptolepis, and Leptolepis have lost the layer of ganoine from most of the skull bones. This is derived relative to the Triassic and Early Jurassic 'pholidophoriforms' with a well-developed layer of ganoine.

Paraleptolepis n. gen., Proleptolepis, and Leptolepis share the presence of $10+9$ principal caudal rays. In contrast, Pholidophorus has $11+$ 11 or $12+12$ and members of the varasichthyid group from Chile have $10+10$ (Arratia 1991: table 2).

Paraleptolepis n. gen., as Leptolepis coryphaenoides, possesses thin cycloid scales all over the trunk. In contrast, information on the scales of Proleptolepis is missing for the European and Chilean specimens.

The morphological differences between Proleptolepis and Paraleptolepis n. gen. are sufficient to show that the new taxon is not congeneric with Proleptolepis.

\section{Phylogenetic relationships of Paraleptolepis n. gen.}

The analysis of the morphological characters of Paraleptolepis n. gen. in comparison to other basal Triassic and Jurassic teleosts finds that the new genus presents a mosaic of characters that can be found in Pholidophorus, Proleptolepis and/or Leptolepis. In addition, Paraleptolepis n. gen. has certain autapomorphies (see Diagnosis) that separate it from the other three genera. To assess the interrelationships of Paraleptolepis n. gen., we performed a cladistic analysis, the results of which are presented below.

We code 84 characters for 14 taxa (Table 1). Figure 13 corresponds to the single shortest tree at 137 evolutionary steps. The consistency index is $0.781(\mathrm{CI}$ excluding uniformative characters is $0.771)$

The phylogenetic relationships among basal teleosts (shown in Figure 13) do not differ from those previously reported by Arratia (1997. 1999). What is new is the placement of Paraleptolepis $\mathrm{n}$. gen. between Proleptolepis and Leptolepis coryphaenoides.

The monophyly of Teleostei (Fig. 13: Node A) is supported by 15 characters. Among these 13 are interpreted as uniquely derived and two as homoplastic (21 and 41). Characters 39[1], 55[1] and $68[2]$ were interpreted by the PAUP program to be present at the level of Pholidophorus and more advanced teleosts. Nevertheless, such an interpretation is uncertain because the information for Pholidophorus is still missing (coded as "?" in Table 1) or is non-applicable (e.g., character 68). With the exception of characters 21 and 40 all others have been extensively discussed in Arratia (1997, 1999). Characters 21[1] (presence of one suborbital bone) and 41[1] (notch at the posterior margin of the preopercle) are homoplastic.

The number of suborbital bones varies among basal teleosts. For instance: one suborbital bone is present at the primitive level of Teleostei; two bones are found in Paraleptolepis n. gen (autapomorphic feature); and the bone in lost in Tharsis and more advanced teleosts, but it is still present in Varasichthys (Arratia 1984) and Bobbichthys (Arratia 1986) from the Jurassic of Chile, and in some ichthyodectiforms (Santos 1950, Patterson \& Rosen 1977).

A notch at the posterior margin of the opercle was interpreted as homoplastic by the PAUP program because the feature is lost at Node D (Leptolepis coryphaenoides plus more advanced teleosts).

The branching of Proleptolepis and more advanced teleosts (Fig. 13: Node B) is supported by eight unique characters and five homoplasies. Among these, character 25[1] (hyomandibula with a preopercular process at its posterior margin) is interpreted as homoplastic because is lost at Node F. Character 25[1] has not been observed in Paraleptolepis n. gen. because its hyomandibula is partially covered by other bones. Character 71[1] that is interpreted as a homoplasy and characters $15[1], 51[1], 72[1]$ and 81[1] 


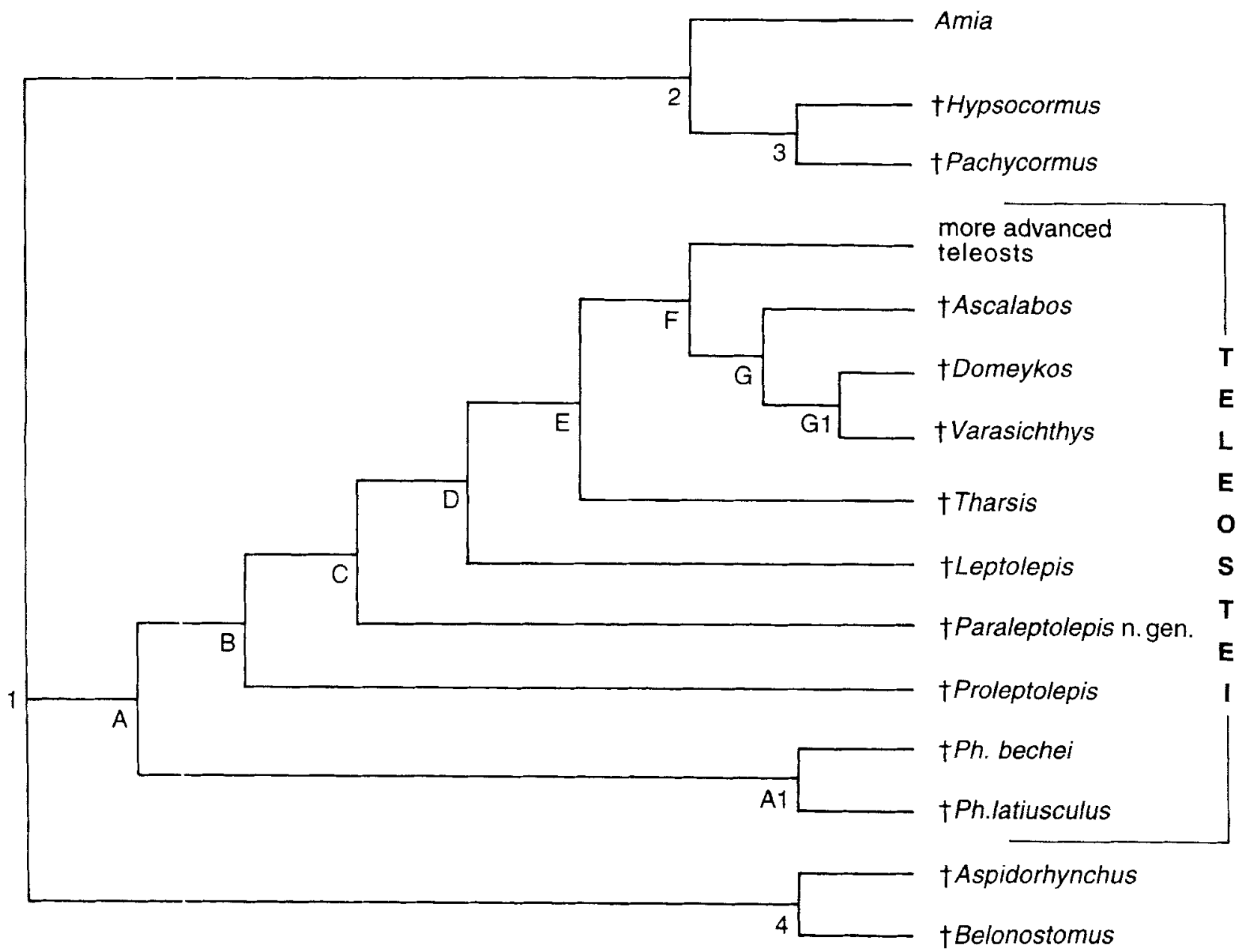

Fig. 13. Hypothesi, of phylogenetic relationships of some primitive fossil teleosts based on a single tree of 137 cvolutionary sleps (for characters and their codings see Appendix and Table 1). The outgroup includes Amia, Aspidorhynchus, Belonostomus, Hypsocommi: and Pacheormus. Uniquely derived characters are indicated by an asterisk. Characters supporting teleostean nodes are: Node A: $2[1]^{*} .3[1]^{*} .7[1]^{*}, 21[1] .27[1]^{*}, 31[1]^{*}, 32[1]^{*}, 37[1]^{*}, 39[1] *, 41[1] .55[1]^{*}, 56[1]^{*}, 67[1]^{*}, 68[2]^{*}$, and $78[1]^{*}$. Node A1: $4[1]^{*}, 23[0], 64[2]$. and $80[1]$. Node B: $15[1]^{*}, 18[1]^{*}, 25[1], 30[1]^{*}, 34[1], 35[1]^{*}, 51[1]^{*}, 65[1]^{*}, 71[1]$, $72[1] * .77[1] .81\left[1 \%\right.$. and $84[1]$. Node $\mathbf{C}: 1+[1]^{*} .20[1] .33[1] * .5[1]^{*}$. $46[1]^{*}$ (see text). $47[1]^{*}$ (see text), 48[1]* (see text), $61[1]^{*}$. and $62[1]$. Vode $\mathbf{D}: 41[0] .52[1]^{*}, 68[1]^{*}, 74[1]^{*}$. and $75[1]^{*}$. Node $\mathbf{E}: 8[1]^{*}, 9[1]^{*}, 12[1]^{*}, 13[1]^{*}, 14[2]^{*}, 16[1]^{*}, 20[0]^{*}$ $\left.21[0]^{*} .24[4]^{*},+6[\because] * 47[2]^{*}, 48[2]^{*} .50[1], 53[1]^{*} .73 / 1\right]$. and $8+[2]$. Node F: $17[1]^{*}, 25[0]$, and $76[1]^{*}$. Node G: $21[1], 40[1]^{*}$, $54[1] .57[1]^{*} .58[1] 77\left[0 \mid .82[1]^{*}\right.$. and $83[1] *$.

that arc still unknown in Proleptolepis and are coded with a question mark in Table 1 . were interpreted as synapomorphies of this node by the PAUP program. However, this interpretation should be revised when the information becomes available.

The monoptyly of Paraleptolepis n. gen. and more advanced teleosts is supported by eight unique characters and three homoplasies at Node C. Among these characters, several (characters 45. 46, 47, 48, 50, 61, and 62) were previously interpreted as having arisen at the level of Leptolepis coryphaenoides and more advanced teleosts (Arratia 1997. 1999). However, the available new information tells us that they arose at a more primitive level. Consequently, characters 45[1] (each caudal vertebral centrum formed by chordacentrum arcocentra. and autocentrum).
46[1] (thin and smooth midcaudal vertebral autocentra). 47[1] (autocentrum of midcaudal vertebrae without cavities for adipose tissue), 48[1] (midcaudal autocentra not constricting the notochord). 50[1] (long epineural process), 61[1] (preural vertebrae with their haemal arches laterally fused to each centrum), and 62[1] (parhypural with haemal arches laterally fused to the centrum) appeared earlier. Character 45[1] is also found in Amia calva. Because of the differences in the relationships between arcocentra and autocentra of Amia and some teleosts, the presence of this character in Amia and in Node $\mathrm{C}$ is interpreted here as independently acquired in both groups.

The grouping of Leptolepis coryphaenoides and more advanced teleosts (Fig. 13: Node D) is supported by four unique features and one homo- 
Table 1. Data matrix of Taxa Set representing 84 characters belonging to fossil taxa. 0 , plesiomorphic state; 1-4. apomorphic states; ?, unclear, owing the preservation of the specimens. Leptolepis coryp.: L. coryphaenoides; Ph. bechei: Pholidophorts bechei, Ph. latiusculus: Pholidophorus latiusculus.

\begin{tabular}{|c|c|c|c|c|c|c|c|c|c|}
\hline & $1-5$ & $6-10$ & $11-15$ & $16-20$ & $21-25$ & $26-30$ & $31-35$ & $36-40$ & $41--45$ \\
\hline 1. Amia & 100 & $\begin{array}{lllllll}0 & 0 & 0 & 0 & 0\end{array}$ & $\begin{array}{lllllllllll}0 & 0 & 0 & 0 & 0\end{array}$ & 40010 & & 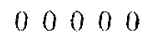 & 000000 & 000000 & $00000 \%$ \\
\hline 2. Ascalabos & $\begin{array}{llllll}0 & 1 & 1 & 0 & 0\end{array}$ & $? 111 ? 0$ & $1 ? ? 2 ?$ & $1 ? 1 ? 0$ & $\begin{array}{llllll}0 & 0 & ? & 4 & 0\end{array}$ & $\begin{array}{lllll}1 & 1 & 0 & 0 & 1\end{array}$ & $? \quad 111111$ & $\begin{array}{lllll}0 & 1 & 1 & 1 & 0\end{array}$ & $\begin{array}{llllll}0 & 0 & 0 & 0 & 1 & 1\end{array}$ \\
\hline 3. Aspidorhynchus & 202000 & 100000 & $1 ? ? ? 0$ & $\begin{array}{llllll}0 & ? & 0 & 0 & 0\end{array}$ & $\begin{array}{llllll}0 & 0 & 1 & 3 & 0\end{array}$ & $\begin{array}{lllll}1 & 0 & 1 & 1 & 0\end{array}$ & $\begin{array}{lllllllll}0 & 0 & 0 & 0 & 0\end{array}$ & $\begin{array}{lllll}1 & 0 & 1 & 0 & 0\end{array}$ & 011100 \\
\hline 4. Belonos tomus & 200200 & 100000 & ? ? ? ? 0 & $\begin{array}{llllll}0 & 0 & 0 & 0 & 0\end{array}$ & $\begin{array}{llllll}0 & 0 & 1 & 3 & 0\end{array}$ & $? \begin{array}{lllll}0 & 1 & 1 & 0\end{array}$ & $? 00000$ & $\begin{array}{lllll}1 & 0 & 1 & 0 & 0\end{array}$ & $\begin{array}{lllll}0 & 1 & 1 & 0 & 0\end{array}$ \\
\hline 5. Domeykos & $0 ? 100$ & ? 11110 & $1 ? ? 2 ?$ & 1.1 $1 ? ?$ & $? 0 ? 4 ?$ & $1 ? 0001$ & $1111 \%$ & 0)? ? ? 1 & $\begin{array}{llllll}0 & 0 & 0 & 0 & 0 & 1\end{array}$ \\
\hline 6. Hypsocormuss & $\begin{array}{llllll}0 & 0 & 0 & 0 & 1\end{array}$ & $000 ? 0$ & ???00 & $\begin{array}{llllll}0 & 0 & 0 & ? & 0\end{array}$ & 000332 ? & $? ? 0 ? 0$ & $? ? ? 00$ & $000 ? 0$ & 000000 \\
\hline 7. Lepolepis coryp. & $\begin{array}{lllll}0 & 1 & 1 & 0 & 0\end{array}$ & $\begin{array}{llllll}0 & 1 & 0 & 0 & 0\end{array}$ & $\begin{array}{llllll}1 & 0 & 0 & 1 & 1\end{array}$ & $\begin{array}{llllllllll}0 & 0 & 1 & 1 & 1 & & \end{array}$ & 100021 & $\begin{array}{lllll}1 & 1 & 0 & 0 & 1\end{array}$ & $\begin{array}{lllll}1 & 1 & 1 & 1 & 1\end{array}$ & $\begin{array}{lllllll}0 & 1 & 0 & 1 & 0\end{array}$ & $\begin{array}{llllll}0 & 0 & 0 & 0 & 1 & 1\end{array}$ \\
\hline 8. Paraleptolepis $\mathrm{n}, \mathrm{g}$. & $? ? 1100$ & ????? & ?? ? ? ? & $? ? 1 ? 1$ & $20 ? 2 ?$ & $? \begin{array}{lllll}\text { ? } & 0 & 0 & 1 & 1\end{array}$ & ?? ? 0 ? & $0 ? ? ? 0$ & $\begin{array}{lllll}1 & 0 & 0 & 1 & 1\end{array}$ \\
\hline 9. Pachycormus & $\begin{array}{llllll}0 & 0 & 0 & 0 & 1\end{array}$ & 000000 & $? ? 000$ & $0 \begin{array}{llllll}0 & ? & 0 & 1 & 0\end{array}$ & 000320 & $1 ? 010$ & $? 0 \begin{array}{lllll}0 & 0 & 0 & 0\end{array}$ & 00 & 00 \\
\hline 10. Ph. bechei & $0 ? 110$ & $\begin{array}{lllll}0 & 1 & 0 & 0 & 0\end{array}$ & 1000000 & $\begin{array}{llllllll}0 & 0 & 0 & 1 & 0\end{array}$ & 100100 & $\begin{array}{lllll}1 & 1 & 0 & 0 & 0\end{array}$ & $\begin{array}{lllll}1 & 1 & 0 & 0 & 0\end{array}$ & $\begin{array}{llllll}0 & 1 & 0 & ? & 0\end{array}$ & () 0 \\
\hline 11. Ph. I & $1 / 2 ? 110$ & $010 ? ?$ & ???? ? & $? ? 010$ & 11020 & $? 10000$ & $? ? 000$ & $0 ? 0$ ? & 1 \\
\hline 12. Proleptolepis & $0 ? 100$ & $01 \% ? ?$ & ? ?? 0 ? & $? ? ? \quad 1 \quad 1 \quad 0$ & $101 \% 1$ & $\begin{array}{llllll}1 & 1 & 0 & 0 & 1\end{array}$ & ? ? $?$ & $\begin{array}{lllllll}0 & 1 & 0 & 1 & 0\end{array}$ & $00 / 10$ \\
\hline 13. Tharsis & $\begin{array}{lllll}0 & 1 & 1 & 0 & 0\end{array}$ & $\begin{array}{lllllllll}0 & 1 & 1 & 1 & 0\end{array}$ & $1111 / 21$ & $\begin{array}{lllll}1 & 0 & 1 & 1 & 0\end{array}$ & $\begin{array}{lllll}0 & 0 & 1 & 4 & 1\end{array}$ & $\begin{array}{lllll}1 & 1 & 0 & 0 & 1\end{array}$ & $\begin{array}{lllll}1 & 1 & 1 & 1 & 1\end{array}$ & 01010110 & $0 \begin{array}{lllll}0 & 0 & 0 & 0 & 1\end{array}$ \\
\hline 14. Varasichthys & $\begin{array}{lllllllll}0 & 1 & 1 & 0 & 0\end{array}$ & $\begin{array}{llllll}0 & 1 & 1 & 1 & 1\end{array}$ & ? 1112 ? & $\begin{array}{lllll}1 & 1 & 1 & 1 & 0\end{array}$ & 1010140 & 110001 & $\begin{array}{llllll}2 & 1 & 1 & 0 & 1\end{array}$ & $\begin{array}{llllll}0 & 1 & 0 & 1 & 1\end{array}$ & $\begin{array}{llllll}0 & 0 & 0 & 0 & 1\end{array}$ \\
\hline
\end{tabular}

\begin{tabular}{llllllll}
\hline $46-50$ & $51-55$ & $56-60$ & $61-65$ & $66-70$ & $71-75$ & $76-80$ & $81-84$ \\
\hline
\end{tabular}

1. Amia

2. Asculabos

3. Aspidorhynchus

4. Belonostomus

5. Domeykos

6. Hypsocomus

7. Leptolepis coryp.

8. Paraleptolepis n. g.

9. Pachycormus

10. Ph. bechei

11. Ph. Latiuscutues

12. Proleptolepis

13. Tharsis

14. Vorasichthys

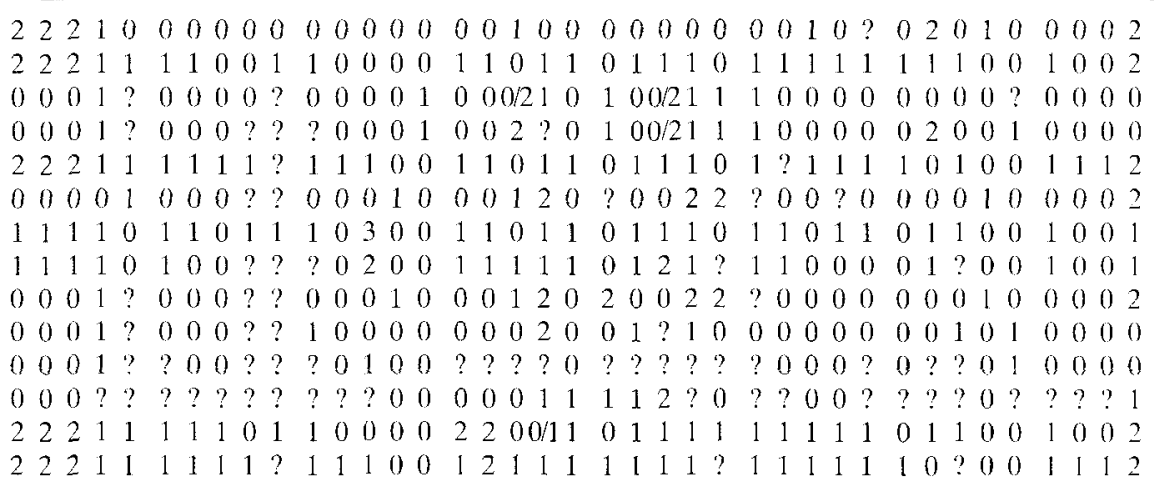

plastic character. Most of these characters have been described and discussed in Arratia (1997, 1999). However, two characters, 41[0] (loss of a notch at the posterior margin of preopercle) and 74[1] (hypaxial fringing fulcra absent), are newly reported features that support this node. Character 41[0] is interpreted as homoplastic because it represents a reversion at this level.

Nodes $E$ to $G$ (Fig. 13A) are not different from those in Arratia (1997, 1999). Node E (Tharsis and more advanced teleosts) is supported by 11 unique characters and five homoplasies. Characters 46[2] (thick and sculptured autocentra), 47[2] (midcaudal autocentra with cavities for adipose tissue), and 48[2] (midcaudal autocentra strongly constricting the notochord) are also found in Amia. However, these characters are interpreted here as independently acquired because of the different positions of these groups in the cladogram.

According to the results of the cladistic analysis, the following features characterize Pholidophorus (represented by the type species $P h$. latiusculus, and Ph. bechei), Proleptolepis, Leptolepis, and Paraleptolepis n. gen.:
Pholidophorus: Parietal $(=$ frontal $)$ bones acutely sharp anteriorly and sutured with rostral bone by a narrow contact (autapomorphy; Arratia 2000 and herein); two supraorbital bones (a homoplastic feature); absence of preural and ural centra (a homoplastic feature); and lepisosteoid-type of scale (a homoplastic feature).

Proleptolepis: "Accessory" suborbital bone and neural spine of ural centrum $1+2$ absent (two homoplastic features).

Leptolepis: Two supraorbital bones (homoplastic feature); and pelvic axillary process formed by a combination of bony elements and modified scales (autapomorphy).

Paraleptolepis n. gen.: Two moderately large suborbital bones (autapomorphy); preopercle subtriangular in profile; large subopercle. broadly expanded postero-ventrally (autapomorphy); pelvic axillary process formed by one small bone only (autapomorphy); and preural centrum 1 with a long neural spine (homoplasy).

As the analysis reveals it is difficult to find unique characters for taxa possessing a generalized morphology, e.g., Proleptolepis, Leptolepis. Consequently, the diagnoses of these primitive 
taxa is based on a combination of only homoplastic characeers or a few unique features and homoplasies. Paraleptolepis n. gen. is remarkable because it possesses a few autapomorphies.

\section{Discussion and conclusions}

The present $f$ ndings demonstrate that the Division Teleostei is supported by numerous characters (Fig. 13). This is because the outgroup is represented by five taxa and the ingroup by nine. When broad sets of characters and of taxa are used. the interpretation changes for many characters (e.g. A:ratia 1997. 1999). Previous characters interpreted as unique for teleosts are found to be homoplastic. An exception is the presence of an elongated postero-ventral process in the quadrate (character 37 herein).

Conventionally, the family Leptolepididae comprised three gencra: Leptolepis Agassiz. Anathalion White, and Thrissops Agassiz. It is now acknowledged that the old Family Leptolepididae was not a natural assemblage. and that Anaethalion belongs in the Elopomorpha and Thrissops in the Ichthycdectiformes. Nybelin (1974) introduced a new interpretation of the Leptolepididae. one that included the genera Leptolepis (with seven species). Proleptolepis (with three species). Tharsis (with one species), and Leptolepides (with one species). The diagnosis of the family as well as the genera were based on combinations of primitive characters. Subsequent studies demonstrate this family as not monophyletic, as conceived by Nybelin (e.g. Patterson 1977. Patterson \& Rosen 1977. Arratia 1996. 1997. 1999). Some of the 'leptolepid" genera were not closely related to Leptolepis coryphaenoides (the type-species) and occupied very different positions on the cladogram: for example. Leptolepides is more closely related to the salmoniforms than to Leptolepis (Arratia 1997. 1999).

This situaticn clearly reflects the difficulty in discovering autapomorphies and synapomorphies in certain grot ps with generalized morphological patterns. Likcwise, the preservation of many socalled leptolepids is poor; a very fragmentary knowledge of some species. such as the proleptolepids, is obtained.

In Patterson's (1977) cladogram. Proleptolepis is in a more rimitive position than Leptolepis coryphaenoide: The same result is observed here, based on a very different set of characters (Fig. 13). It is intcresting to note that Nybelin (1974: following a non-cladistic approach) pro- posed that within leptolepids the most primitive are the proleptolepids, because they retain more plesiomorphic characters than Leptolepis. He mentioned the presence of an "accessory" suborbital, a notch in the posterior margin of the preopercle. a shallower lower jaw, etc. In his discussion. Leptolepis is considered more derived than Proleptolepis because of several characters, including the presence of a larger premaxilla, smaller suborbital, absence of a notch in the posterior margin of preopercle, deeper lower jaw, etc. (see Nybelin 1974: 183). Although that his phylogenetic interpretation was mostly based on primitive characters, the results of the cladistic analysis performed here, based on a broad set of characters, support Nybelin's conclusion that Proleptolepis is more primitive than Leptolepis.

The newly described fish in this study, Paraleptolepis wiedenrothi, presents a combination of proleptolepid and leptolepid characters. Howcver. the position of Paraleptolepis n. gen. in the cladogram (Fig. 13) (between Proleptolepis and Leptolepis) and the autapomorphies of the new fish, justify the establishment of a new genus and species different from other Early Jurassic teleosts.

\section{Acknowledgements}

Wo are very much indebted to Herrn Kurt Wiedenroth, Garbsen. who collected the specimen and unselfishly gave it to us for studv: We thank the following curators and institutions for loan of specimens: C. H. von Daniels (Bundesanstalt für Geowissenschaften und Rohstoffe, Hannover); D. Frassinetti (Museo Nacional de Historia Natural, Santiago), $H$. Jahnke (Institut und Museum für Geologie und Paläontologie. Georg-August Universität, Göttingen); and F. Jenkins (Museum of Comparative Zoology. Harvard University; Massachusetts).

Our special thanks to M. Gottfried (Michigan), L. Grande (Chicago). H.-P. Schultze (Berlin), L. Taverne (Brussels), and M. V. H. Wilson (Edmonton) for reviewing the manuscript, to H.-P. Schultze for preparing the Zusammenfassung, to Mr. J.-P. Mendau (Museum für Naturkunde, Berlin) for his valuable holp with Figures $4-13$ based on the original drawings by G. Arratia and Mrs. W. Harre (Museum für Naturkunde, Berlin) for preparing the photographs.

\section{Literature}

Agassiz. L. 1832. Untersuchungen über die fossilen Fische der Lias-Formation. - Jahrbuch für Mincralogie, Geognosie und Petrefaktenkunde 3: $139-149$.

Arratia. G. 1981 . Varasichthvs ariasi n. gen. et sp. from the Upper Jurassic of Chile (Pisces. Teleostei. Varasichthyidac n. fam.), - Palaeontographica A 175: 107-139.

- 1984. Some morphological features of Varasichthys ariasi Arratia (Pisces. Telcostei) from the Late Jurassic of Chile. - Paläontologische Zeitschrift 58 (1/2): 149-163. 
- 1986. New Jurassic fishes (Teleostei) of Cordillera de Domeyko, Northern Chilc. - Palacontographica A 192: $75-91$.

- 1987. Jurassic fishes from Chile and critical comments. In Volkheimer, W. \& Musacchio, E. A. (eds). Bioestratigrafía de los Sistemas Regionales del Jurásico y Cretácico de América del Sur: 257-286. Comité Sudamericano del Jurásico y Cretácico. Mendoza. Argentina.

- 1991. The caudal skeleton of Jurassic teleosts; a phylogenetic analysis. In Chang, M.-M., Liu, Y.-H. \& Zhang, G. R. (eds). Early Vertebrates and Related Problems in Evolutionary Biology: 249-340. Science Press, Beijing.

- 1994. Phylogenctic and palcogeographic relationships of the varasichthyid group (Teleostei) from the Late Jurassic of Central and South America. - Revista Geológica de Chile 21: $119-165$.

- 1996. Reassessment of the phylogenetic relationships of certain Jurassic teleosts and their implications on teleostean phylogeny. In Arratia, G. \& Viohl, G. (eds). Mesozoic Fishes - Systematics and Paleoecology: 219-242, Verlag Dr. F. Pfeil, München.

- 1997. Basal teleosts and teleostean phylogeny. - Palaeo Ichthyologica 7: 1-168

- 1999. The monophyly of Teleostei and stem-groups teleosts. Consensus and disagreements. In Arratia, G. \& Schultze, H.-P. (eds). Mesozoic Fishes 2 - Systematics and Fossil Rccord: 265-334, Verlag Dr. F. Pfeil, München.

- 2000. New teleostean fishes from the Jurassic of southern Germany and the systematic problems concerning the 'pholidophoriforms'. - Paläontologische Zeitschrift $\mathbf{7 4}$ $(1 / 2): 113-143$.

Arratia, G. \& Cloutier, R. 1996. Reassessment of the morphology of Cheirolepis canadensis (Actinopterygii). In Schultze, H.-P. \& Cloutier, R. (eds). Devonian Fishes and Plants of Miguasha: 165-197, Verlag Dr. F. Pfeil, München.

Arratia, G. \& Schultze, H.-P. 1987. A new halecostome fish (Actinopterygii, Osteichthyes) from the Late Jurassic of Chile and its relationships. - Dakoterra 3: 1-13.

- 1990. The urohyal: development and homology within osteichthyans. - Journal of Morphology 203: 247-282.

- 1991. The palatoquadrate and its ossifications: Development and homology within osteichthyans. - Journal of Morphology 208: 1-81.

-- 1992. Reevaluation of the caudal skeleton of certain actinopterygian fishes. III. Salmonidae. Homologization of caudal skeletal structures. - Journal of Morphology 214: $187-249$

- 1999. Mesozoic fishes from Chilc. In Arratia, G. \& Schultze, H.-P. (eds). Mesozoic Fishes 2 - Systematics and Fossil Record: 565-593. Verlag Dr. F. Pfeil, München.

Brito, P. 1997. Révision des Aspidorhynchidae (Pisces, Actinopterygii) du Mésozoïquc: ostéologie, relations phylogénétiques, donnée environnementales et biogéographiques. - Geodiversitas 19 (4): $681-772$.

Bronn, H. 1830. Über zwei fossile Fischarten: Cyprinus coryphaenoides und Tetragonolepis semicinctus aus dem Gryphitenkalke bei Donaueschingen. - Jahrbuch für Mineralogie. Geognosie und Petrefaktenkunde 1: 14-30.

Delsate, D. 1997. Actinoptérygiens du Toarcien inférieur du Grand Duché de Luxembourg: présence de Leptolepis normandica NYBELIN 1962 (Téléostéen) avec otolithes in situ. - Travaux scientifiques du Musée national d'Histoire naturelle de Luxembourg 27: 105-129.

- 1999. Haasichthys michelsi, nov. gen., nov. sp., un nouveau Pachycormiforme (Osteichthyes, Actinopterygii) du Toarcien inférieur (Jurassique) luxembourgeois. - Travaux scientifiques du Muséc national d'Histoire naturelle de Luxembourg 32: 87-140.

- Grande, L. \& Bemis, W. 1998. A comprehensive phylogenetic study of amiid fishes (Amiidae) based on comparative skeletal anatomy. An empirical search for intercon- nected patterns of natural history. - Journal of Vertebrate Paleontology 18, supplement 1. Memoir 4: $1-690$.

Hauff, B. \& Hauff, R. B. 1981. Das Holzmadenbuch. $3^{\text {rd }}$ ed.. 136 pp. Selbstverlag, Holzmaden.

Jessen, H. 1972. Schultergürtel und Pectoralllosse bei Actinopterygiern. - Fossil and Strata 1: 1-101.

Jollie, M. 1962. Chordate Morphology. xiv + 478 pp. Rheinhold Books. New York.

Leach, W. E. 1822. Dapedium politum. In Beche H. T. de la (ed). Remarks on the geology of the south coast of England, from Bridport Harbour, Dorset. to Babbacombc Bay, Devon. - Transactions of the Geological Society of London, Seric 2, 1: 45.

Mainwaring, A. J. 1978. Anatomical and systematic revision of the Pachycormidae, a family of Mesozoic fossil fishes. - Unpublished Doctoral thesis: 127 pp. Westfield College, London.

Nybelin. O. 1963. Zur Morphologie und Terminologic des Schwanzskelettes der Actinopterygier. - Arkiv för Zoologi, serie 2, 15 (35): 485-516.

- 1966. On certain Triassic and Liassic representatives of the family Pholidophoridae s. str. - Bulletin of the British Museum of Natural History, Geology 11: $351-432$.

- 1974. A Revision of the Leptolepid Fishes. - Acta Regiae Societatis Scientiarum et Litterarum Gothoburgensis. Zoologica 9: 1-202.

Patterson, C. 1968. The caudal skeleton in Lower Liassic pholidophorid fishes. - Bulletin of the British Museum of Natural History, Geology 16: 201--239.

- 1975. The braincase of the pholidophorid and leptolepid fishes. with a review of the actinopterygian braincase. Philosophical Transactions of the Royal Society of London, Series B, Biological Sciences 269: 275-579.

- 1977. Contribution of paleontology to teleostean phylogeny. In Hecht, M. K., Goody, P. C. \& Hecht. B. M. (eds) Major Patterns in Vertebrate Evolution. NATO Advanced Study Institute Series, Serie A: 579-643.

Patterson, C. \& Rosen, D. E. 1977. Review of ichthyodectiform and other Mesozoic teleost fishes and the thcory and practice of classifying fossils. - Bulletin of the American Museum of Natural History 158: $81-172$.

Rayner, D. H. 1937. On Leptolepis bronni Agassiz. - Annals and Magazine of Natural History 19: 46-74.

Santos, R. da Silva. 1950. Anaedopogon. Chiromvstus e Ennelichthys com sinonimos de Cladocyclus, da familia Chirocentridae. - Anais, Academia brasileira de Ciências 22 $123-234$.

Schultze, H.-P. 1966. Morphologische und histologische Untersuchungen an den Schuppen mesozoischer Actinopterygier (Übergang von Ganoid- zu Rundschuppen). Neues Jahrbuch für Geologie und Paläontologie. Abhandlungen 126: $232-314$.

- 1993. Pattens of diversity in the skulls of jawed fishes. In Hanken, J. \& Hall, B. K. (eds.). The Skull. Volume 2. Patterns of Structural and Systematic Diversity: 189-254. The University of Chicago Press, Chicago and London.

- 1996. The scales of Mesozoic actinopterygians. In Arratia. G. \& Viohl, G. (eds). Mesozoic Fishes - Systematics and Paleoecology: 243-259. Verlag Dr. Pfeil. München.

Schultze, H.-P. \& Arratia, G. 1989. The composition of the caudal skeleton of telcosts (Actinopterygii; Oteichthyes).

Zoological Journal of Linnean Society. London 97: $189-231$.

Schultze, H.-P. \& Arsenault, M. 1985. The panderichthyid fish Elpistostege: A close relative to tetrapods? - Palaeontology 28: 293-309.

Stensiö, E. A: son. 1925. Triassic fishes from Siptzbergen. Part II. - Kungliga Svenska VetenskapsAkademiens Handlingar, $3^{\text {rd }}$ Series, 2 (1): $1-261,34$ pls.

Swofford, D. 1998. PAUP*: Phylogenetic analysis using parsimony (and other methods), version 4.0b2a. Sinauer Associates, Sunderland, MA. 
Taverne. L. 1975. Considérations sur la position sỵstématiqute des genres fossiles Leptolepis et Allothrissops au sein des télćostéens pr mitils et sur loorigine et le polyphylétisme des poissons tźléostéens. - Bulletin de l'Académie Royale de Belgitue (Classe de Sciences), Se série. 61: $336-371$

Thies. D. 1985. Funde von Acidomynchus brevirostris (WoODWARL 1895) aus dem Posidonienschicfer (UnterToarcium) N'V-Deutschlands. - Palaeontographica A 187: $183-203$

- 1988. Dapedinn pholidomm (Agassiz 1832) ? (Pisces. Actinopterygii) a is dem Unter-Toarcium NW-Deutschlands. - Geologica e: Palacontologica 22: 89-121.

- 1989. Der Hirrschadel und das Gehirn von Tetragonolepis semicincta Bronn 1830 (Actinopteryeii. Semionotiformes). - Palaconogriphica A 209: 1-32.

- 1991. The osterlogy of the bony fish Tetragonolepis semicincra Bronn 1830 (Actinopterygii. Semionotiformes) from the Early Jurassic (Lower Toarcian) of Germany: Gcologica et Palacontologica 25: 251-297.

Tombs. H. A. \& Rixon. A. E. 1959. The use of acids in the preparation of vertebrate fossils. - Curator 2: $304-312$.
Weitschat. W. 1973. Stratigraphic und Ammoniten des höheren Untertoarcium (oberer Lias e) von NW-Deutschland. - Geologisches Jahrbuch A8: 3-81.

Wenz. S. 1968. Compléments à l'élude des poissons actinoptérygiens du Jurassique français. - Cahiers de Paléontologie. $276 \mathrm{pp}$. Centre National de la Rccherche Scientifique. Paris.

Woodward. A. S. 1895. Catalogue of the Fossil Fishes in the British Museum (Natural History). Part III. - XXIV + $54+$ pp. Trustees of the British Museum, London.

Wunnenberg. C. 1950. Zur Ausbildung des Posidonienschiefers in der Umgebung von Braunschweig unter besonderer Berücksichtigung der Fossilisation. - Neues Jahrbuch für Geologie und Paläontologie, Monatshefte 1950: $146-182$.

Zambelli. R. 1975. Note sui Photidophoriformes. I. - Parapholidophorts mbelini gen. n. sp, n. - Rendiconti Instituto Lombardo. Academia di Scienze e Lettere 109: 3-49.

- 1986. Note sui Pholidophoriformes. VI Contributo. Pholidophorinae subfamiglia nuova del Triassico Superiore. Revista del Musto Civico di Scienze Naturati "E. Caffi" 10: $1-32$.

\section{Appendix: List of characters}

The phvlogenctic relationships of certain teleosts are based on the features listed below. [0] represent the plesiomorphic character statc and [1]. [2]. [3]. and [4] the apomorphic character states. The outgroup used to polarize characters includes taxa that previously have been proposed as sister group of teleosts such as Amia, Aspidomynchus, Belonostomus, Hypsocormus and Pachycomms Most characters are from Arratia (1997. 1999): in other cases the appropriate author(s) are cited. Characters 20.21 .40 .51 .74 . and 84 are new.

1. Postparietal (= parietal) bones: [0] separated from each other: [1] fused to cach other: [2] fused with other skull bones

2. Supraoccipital bone: [0] absent: [1] present (extending forward in roof of otic region). (Modified from Patterson 1977).

3. Parjetal ( = frontal) bones: [0] not distinct broadening between anterior and posterior parts; [1] distinctly broader posteriorly: but long: and narrow anteriorly: [2] Non-applicable: fused to other cranial bones. (Arratia \& Schultze 1987).

4. Parictal (= frontal) boncs: [0] brodd anteriorly and sutured with rostral bone by a broad contact; [1] acutely sharp anteriorly and sutured with rostral bone by a narrow contact.

5. Large compound rostro-dermethmoid meeting the parictal (= frontal): [0] absent: [1] present. (Mainwaring 1978).

6. Interparietal ( = interfrontal) suture: $[0]$ smooth (sutura hamonica): [1] serrata or dentata.

7. Nasal bones: [)] close together medially: [1] separated by the parietal (- frontal) bones.

8. Sutures betwean all cartilage bones in the braincase: [0] lost ontogenetically: [1] retained throughout life. (Patterson \& Rosen 1977).

9. Parasphenoid: [0] with small teeth: [1] toothless. (Modilied from Arratia 1999).

10. Parasphenoid: [0] short. not extending posterior to basioccipital: [1] long. extending posterior to basioccipital bone.

11. Vomer (in adults): [0] paired: [1] unpaired.

12. Ossificd aortic canal: [0] present: [1] absent.

13. Canals for occipital arteries in basioccipital bone: [0] present: [1] absent

14. Spiracular can 1 : [0] developed: [1] greatly reduced: [?] absent.

15. Anterior myodome: [0] as a median compartment: [1] paired.

16. Foramen for glossopharyngeal nerve in exoccipital: [0] absent: [1] present. (Patterson \& Rosen 1977).

17. Foramen for agus nerve: [0] placed in the prootic or at the suture between prootic and exocipital; [1] placed in the posterolateral face of exoccipital alone.

18. Cephalic sensory canals with [0] branched tubules: [1] simple tubules. (Modified from Arratia 1999).

19. Antorbital bore: [0] absent: [1] present. (Modified from Arratia 1999).

20. Third infraorb tal bone: [0] slightly projected postero-rentrally or posteriorly: [1] strongly projected postero-ventrally.

21. Number of suhorbital bonc(s) (without "accessory" suborbital): [0] none: [1] one: [2] two or more.

22. "Accessory" suborbital bone: [0] absent: [1] present.

23. Number of supraorbital bone(s): [0] two or more: [1] one: [2] none: [3] Non applicable: fused with other bone forming the supraorbitoder mosphenotic.

24. Sclerotic ring ussification: [0] absent: [1] a complete ring of four bones: [2] a complete ring of two sclerotic bones oricnted anterior and posterior to eve: [3] a complete ring of two sclerotic bones oriented dorsal and ventral to eye; 14$]$ an incomplete ring of two bones oriented anterior and posterior to eve.

25. Hyomandibular bone: [0] lacking a preopercular process: [1] with a preopercular process at its posterior margin.

26. Svmplectic: [0] articulates with lower jaw: [1] not articulate with lower jaw

27. Premaxilla: [0] fixed: [1] mobile. (Patterson \& Rosen 1977).

28. Promaxillat fo ming a rostral tube that projects into the ethmoidal region: [0] absent: [1] present. (Brito 1997).

29. Supramaxilla $(a \mathrm{e})$ : [0] dorsal to the dorsal margin of maxilla: [1] placed posteriorly to maxilla.

30. Quadrate-man Jibular articulation: $[0]$ posterior to orbit: [1] placed below the posterior half of the orbit.

31. Articular bone: [0] not fused to angular and retroarticular: [1] fused with angular and retroarticular bones; [2] fused with angular but not retroarticular. (Modified from Arratia 1999).

32. Coronoid bone's in lower jaw: 10] present: [1] absent. (Patterson 1977 ). 
33. Suprangular bone in lower jaw: [0] present: [1] absent.

34. Postarticular process of lower jaw: [0] poorly developed; [1] well developed.

35. Notch in the decp dorsal ascending margin of the dentary: [0] absent; [1] present.

36. Toothed predentary: [0] absent; [1] present. (Brito 1997).

37. Elongate postero-ventral process of quadrate: [0] absent; [1] present. (Arratia \& Schultze 1991).

38. Gular plate: [0] present; [1] absent.

39. Two ossified hypohyals: [0] absent: [1] present. (Arratia \& Schultze 1990).

40. Postero-ventral region of preopercle: [0] narrow or slightly expanded: [1] broadly expanded.

41. Notch at the posterior margin of preopcrcle: [0] absent; [1] present.

42. Preopercular sensory canal: [0] close to the anterior margin of a a slightly triangular or slightly boomerang-shaped preopercle: [1] very postcriorly placed in a peculiarly triangular preopercle.

43. Interopercular bone: [0] present; [1] absent. (Brito 1997).

44. Large and postero-ventrally broadly expanded subopercular bone: [0] absent: [1] present.

45. Each vertebral centrum of the caudal region of adult individual formed by: $[0]$ mineralized chordacentrum and arcocentra: [1] chordacentrum, arcocentra and autocentrum.

46. Midcaudal vertebral autocentra: [0] absent; [1] prescnt, thin and smooth: [2] present, thicker and sculptured. (Modified from Arratia 1991, 1997).

47. Autocentrum of midcaudal vertebrae: [0] absent; [1] present. but without cavities for adipose tissue: [2] present. with cavities for adipose tissue.

48. Midcaudal autocentra: [0] absent; [1] present, not constricting the notochord; [2] present, strongly constricting the notochord.

49. Neural spines of caudal region: [0] paired; [1] unpaired.

50. Interhaemal bones: [0] present; [1] absent.

51. In adult individual. elongate epineural processes of neural arch: [0] absent: [1] present. (Modified from Arratia 1999).

52. Solidly ossified epineural process: [0] absent; [1] present.

53. Epipleural intermuscular bones: [0] absent; [1] present.

54. Supracleithrum with main lateral line emerging: [0] at its upper half; [1] at its postero-ventral margin. (Modified from Arratia 1999).

55. Four proximal pectoral radials: [0] absent; [1] present. (Jessen 1972).

56. Pectoral propterygium: [0] unfused with first pectoral ray: [1] fused with first pecioral ray. (Jessen 1972. Patterson] 1977).

57. Pectoral axillary process: [0] absent: [1] present; formed by small bony elements. (Modified from Arratia 1999).

58. Pelvic axillary process: $[0]$ absent; [1] present; formed by an elongate bone; [2] present: formed by a combination of bony clement(s) and modified scales. (Modified from Arratia 1999).

59. Pectoral fin: [0] round or slightly triangular; [1] scythe-like. (Mainwaring 1978).

60. Dorsal and anal fins: [0] anteriorly placed; [1] posteriorly placed.

61. Hacmal arches of preural vertebrae (without preural centrum 1) of adult individuals: [0] autogenous; [1] laterally fused to their respective autocentra; [2].

62. Parhypural (in adults) with haemal arch: [0] autogenous; [1] laterally fused to its autocentrum: [2] laterally unfused to its autocentrum.

63. Neural spine of preural centrum 1: [0] rudimentary or short; [1] long, close to, or reaching the dorsal margin of the body: [2] absent.

64. Number of independent ural centra in adults: [0] more than two; [1] two or one; [2] no ural centra. (Modificd from Patterson 1977).

65. First two hypurals supported by: [0] notochord or two independent ural centra: [1] a single centrum.

66. Neural spine of ural centrum 1 and 2 or 'first' ural centrum: [0] present: [1] absent: [2] other condition: preural centrum 1 fused with ural centrum(tra).

67. Only ural neural arches modificd as uroneurals: [0] absent; [1] present. (Modified from Patterson 1977).

68. First uroneural reaches: [0] no uroneural present; [1] preural centrum 4 or 3; [2] 'first' ural centrum: [3] no preural centril. (Modified from Arratia 1997, 1999).

69. Arrangement of hypural and caudal fin rays: [0] Each hypural normally articulated with one caudal ray: [1] each hypural normally articulates with a few caudal rays: [2] fusion of hypurals. (Modified from Grande \& Bemis 1998).

70. Number of hypurals in adult individuals: [0] ten or more: [1] nine or less; [2] fusion of hypurals into one hypural plate. (Modified from Arratia 1997, 1999).

71. Bases of hypurals 1 and 2: [0] not joined by cartilage in any growth stage: [1] joined by cartilage and/or bone in some growth stage.

72. Number of urodermals or 'urodermals": [0] none; [1] two "urodermals'.

73. Fringing fulcra preceeding the first principal caudal ray: [0] present; [1] absent.

74. Fringing fulcra preceeding the last principal caudal ray: [0] present: [1] absent.

75. Epaxial and hypaxial basal fulcra: [0] present; [1] absent.

76. Dorsal segmented precurrent rays: [0] absent; [1] present,

77. Number of principal caudal rays: [0] twenty or more; [1] nineteen; [2] fewer than ninetecn.

78. Dorsal processes of the bases of the innermost principal caudal rays of upper lobe: [0] absent: [1] present.

79. Amioid-type of scales or scales with radial structures (sensu Schultze 1996): [0] absent: [1] present.

80. Lepisosteoid-type of scale: [0] absent; [1] present.

81. Cycloid scales: [0] absent: [1] present.

82. Cycloid scales posterior to the pectoral girdle with circuli crossed by transverse lines in the middle ficld: $\{0]$ abscit: [1] present.

83. Cycloid scales with crenulate posterior margin: [0] absent; [1] present.

84. Ganoine layer: [0] on all cranial bones; [1] on some cranial bones; [2] lost. 